\title{
ANALIZA SOCIJALNOG PODUZETNIŠTVA U HRVATSKOJ S KOMPARATIVNIM OSVRTOM NA REGULATORNI OKVIR ${ }^{1}$
}

Sažetak: Rad pruža komparativnu analizu regulatornih okvira društvenog poduzetništva izabranih država članica EU-a iz koje se nastoje dobiti relevantni uvidi za Hrvatsku. Poseban doprinos rada je u SWOT analizi društvenog poduzetništva u RH koja se temelji na saznanjima dobivenim u polustrukturiranim intervjuima s ključnim akterima i poznavateljima društveno-poduzetničke scene u RH. Cilj je rada dodatno afirmirati društveno poduzetništvo i njegov potencijal te produbiti konstruktivne rasprave o unaprjeđivanju istoga.

Ključne riječi: $\quad$ socijalno poduzetništvo, društveno poduzetništvo, zadruga, socijalna ekonomija, regulatorni okvir

\section{UVOD}

Iako je ideja solidarnosti, uključivanja i stvaranja nove društvene vrijednosti kroz poslovne aktivnosti koju danas imenujemo društvenim poduzetništvom ${ }^{2}$ u Hrvatskoj prisutna više od 150 godina na tradicijskim temeljima zadruga, trenutačna je slika prilično nejasna i fragmentirana. Postojeći administrativni, normativni, investicijski i promidžbeni potporni stupovi koji bi, prema općim ciljevima Strategije za razvoj društvenog poduzetništva, trebali podupirati društveno poduzetničko djelovanje, ne funkcioniraju dovoljno efikasno. S druge strane, druš-

* Ina Vojvodić, mag. iur., adresa za korespondenciju: Male Putine 4, 10090 Zagreb, Republika Hrvatska. Adresa e-pošte: ina. vojvodic@gmail.com. ORCID: https://orcid.org/0000-0002-8901-119X.

** Dr. sc. Ružica Šimić Banović, docentica, Pravni fakultet Sveučilišta u Zagrebu, Trg Republike Hrvatske 14, 10000 Zagreb, Republika Hrvatska. Adresa e-pošte: ruzica.simic@pravo.hr. ORCID: https://orcid.org/0000-0001-6527-2726.

1 Rad se dominantno temelji na diplomskom radu Ine Vojvodić "Pregled društvenog poduzetništva u Republici Hrvatskoj s komparativnim osvrtom na regulatorni okvir" predanom i obranjenom u veljači 2017. na Pravnom fakultetu Sveučilišta u Zagrebu na Katedri za ekonomske znanosti, pod mentorstvom doc. dr. sc. Ružice Šimić Banović. Inicijalni rad je za potrebe članka revidiran i ažuriran. Autorice su zahvalne doc. dr. sc. Danijelu Baturini na iznimno korisnim sugestijama primijenjenim u finalizaciji ovog članka.

2 Pojmovi društveno i socijalno poduzetništvo uglavnom se koriste kao sinonimi u znanstvenoj i stručnoj literaturi, stoga se u ovom radu koriste naizmjence. Rasprava o primjerenijem pojmu u hrvatskom jeziku izvan je ciljeva ovog rada. 
tvena poduzeća najaktivniji su akteri socijalne ekonomije u EU-u i svijetu te se sustavno radi na podršci njihovu rasta i razvoja.

Ovaj se rad temelji na analizi postojećih dokumenata, stručnih i znanstvenih članaka koji obrađuju društveno poduzetništvo u Hrvatskoj, EU-u i svijetu. Poseban je doprinos rada u saznanjima dobivenim kroz polustrukturiranih intervjua s vodećim poznavateljima i akterima hrvatske društveno-poduzetničke scene. Korišten je namjerni uzorak, imajući u vidu da se tako osiguravaju information rich cases. ${ }^{3}$ Odgovarajući odabir ispitanika i prepoznavanje najboljih praksi osiguravala je pozicija istraživača insidera (suautorica članka Ina Vojvodić) koja se rastuće percipira kao izuzetno vrijedna i legitimna uzimajući u obzir moguće metodološke izazove i istraživačke prednosti. ${ }^{4}$ Svi su ispitanici autorizirali svoje anonimne i neanonimne (javne) izjave (iz transkribiranih intervjua) te su elektronskim putem dali suglasnost za objavu u znanstvenom članku.

Članak stoga predstavlja komparativni pregled regulatornog okvira društvenog poduzetništva u većini država članica EU-a (Poglavlje 2) te posebno obrađuje aktualne snage, slabosti, prilike i prijetnje društvenom poduzetništvu u RH te daje smjernice rješavanja slabosti i prijetnji kao i korištenja snaga i prilika (Poglavlje 3). Konačno, rad se zaključuje glavnim naglascima ovoga istraživanja te preporukama javnih politika i reformi u sferi društvenog poduzetništva (Poglavlje 4). Cilj je rada dodatno afirmirati društveno poduzetništvo i njegov potencijal te potaknuti konstruktivne rasprave o unaprjeđivanju istoga, posebno u sferi regulatornog okvira.

\section{SOCIJALNA PODUZEĆA U EUROPSKOM KONTEKSTU}

Univerzalno prihvaćena definicija socijalne ekonomije ${ }^{5}$ (sužavajući se prema užem pojmu društvenog poduzetništva) ne postoji iako neupitnom ostaje činjenica da ona u Europi postaje "učinkovit alat za rješavanje pitanja siromaštva, kreiranje zapošljavanja i poticanje socijalne kohezije". ${ }^{6}$ Samo tradicionalni akteri socijalne ekonomije (zadruge, udruge, fondacije i uzajamna društva) čine impresivnu brojku od dva milijuna društveno-ekonomskih entiteta te znatno doprinose cjelokupnom europskom poslovanju (od 10 do 12\%) zapošljavajući 14,5 milijuna ljudi odnosno 6,5\% ukupno radno aktivne populacije. ${ }^{7} \mathrm{U}$ Tablici 1 nalaze se prihvaćene definicije socijalnih poduzeća i kriteriji za iste.

3 Patton, M. Q., Qualitative Research and Evaluation Methods. Thousand Oaks, CA: Sage, 2002.

4 Banks, J. A., The Lives and Values of Researchers: Implications for Educating Citizens in a Multicultural Society. Educational Researcher, vol. 27, br. 7, 1998., str. 4.-17.

Chavez, C., Conceptualizing from the inside: Advantages, complications, and demands on insider positionality. The Qualitative Report, vol. 13, no. 3, 2008, str. 474.-494.

5 Socijalna ekonomija danas uključuje privatne, formalno organizirane organizacije s autonomijom u odlučivanju i slobodnim članstvom koje proizvodi netržišne usluge za kućanstva i čiji viškovi, ako ih ima, ne mogu biti prisvojeni od ekonomskih agenata koji ih stvaraju, kontroliraju ili financiraju - prema European Economic and Social Committee. The social economy in the European Union - Report by José Luis Monzón \& Rafael Chaves, 2012 http://www.eesc.europa.eu/resources/docs/qe-30-12790-en-c.pdf, pristupljeno 12. prosinca 2016.

6 European Commission - Social Business Initiative. http://ec.europa.eu/growth/sectors/social-economy/enter prises-en, pristupljeno 10. prosinca 2016.)

7 Valja napomenuti da ne postoji komparativna statistika o ukupnoj društvenoj ekonomiji zbog nedostatka harmonizirane definicije kao i teškoća u preciznom i redovitom praćenju podataka u zemljama članicama. 
Tablica 1. Definicije i kriteriji za identificiranje socijalnih poduzeća

\begin{tabular}{|l|l|}
\hline Izvor & Definicija \\
\hline $\begin{array}{l}\text { Europska komisija } \\
\text { 2011. }\end{array}$ & $\begin{array}{l}\text { Tvrtke koje pružaju socijalne usluge i/ili robu osjetljivijim skupi- } \\
\text { nama (pristup stanovanju, zdravstvenoj skrbi, pomoć za stare ili } \\
\text { hendikepirane osobe, uključivanje ranjivih skupina, skrb za dje- } \\
\text { cu, pristup zapošljavanju i obuci, menadžment skrbi) i /ili tvrtke } \\
\text { s metodom proizvodnje dobara ili usluga društvenog cilja (socijal- } \\
\text { na i profesionalna integracija preko pristupa zapošljavanja osoba } \\
\text { u nepovoljnom položaju, posebno s nedovoljnim kvalifikacijama ili } \\
\text { društvenim ili profesionalnim problemima koji dovode do isključi- } \\
\text { vanja i marginalizacije), ali čija aktivnost može biti izvan područja } \\
\text { pružanja socijalnih dobara ili usluga. }\end{array}$ \\
\hline $\begin{array}{l}\text { EMES - } \\
\text { Europska istraživačka } \\
\text { Emreža, 20019 } \\
\text { Energence of Social }\end{array}$ & $\begin{array}{l}\text { "Organizacija s eksplicitnim ciljem usmjerenim razvoju i koristi za- } \\
\text { jednice, osnovana od strane skupine pojedinaca, kod koje materi- } \\
\text { jalni interesi kapitalnih investitora podliježu ograničenjima. Takve } \\
\text { organizacije kao najveće vrijednosti ističu autonomiju, nezavisnost } \\
\text { djelovanja i preuzimanje financijskih/ekonomskih rizika perma- } \\
\text { nentnih društveno-ekonomskih aktivnosti." }\end{array}$ \\
$\begin{array}{l}\text { Najvažniji ekonomski kriteriji društvenih poduzeća: } \\
\text { 1. kontinuirana aktivnost proizvodnje prodaje dobara/usluga } \\
\text { 2. visok stupanj autonomije } \\
\text { 3. poduzimanje značajnog ekonomskog rizika } \\
\text { 4. minimalni broj plaćenih radnika. } \\
\text { Socijalni kriteriji: } \\
\text { 1. izričit cilj društvene korisnosti } \\
\text { 2. građanska inicijativa } \\
\text { 3. donošenje odluka nije uvjetovano vlasničkim udjelom } \\
\text { 4. participirajući karakter koji uključuje sve dionike procesa od ko- } \\
\text { risnika do pružatelja usluga } \\
5 . \text { ograničena distribucija profita. }\end{array}$ \\
\hline
\end{tabular}

Još je 1989. Europska komisija u prvom Izvješću o poduzećima socijalne ekonomije predložila donošenje Statuta Europske zadruge, Europskog uzajamnog društva i Europskog udru-

8 Iz definicije Social Business Initiative http://ec.europa.eu/internal-market/social-business/index-e, pristupljeno 12. siječnja. 2017.

9 EMES - mrežna stranica http://www.emes.net, pristupljeno 15. prosinca 2016.

10 Definicija preuzeta iz: Lupšić, D., Bajok, I.. Medić, M., Glavina Petričević, S., Petričević, T., Fruchterman, J., Poduzetništvo u službi zajednice - Zbornik radova o društvenom poduzetništvu, Nacionalna zaklada za razvoj civilnog društva, Zagreb, 2012. 
ženja, no tek 2003. usvojen je (samo) Statut Europskih zadruga. ${ }^{11}$ Zadruge su u Europi dobile svoju harmoniziranu pravnu osnovu i danas predstavljaju snažan potencijal europskog ekonomskog prostora zapošljavajući oko 4,5 milijuna ljudi u EU-u. Osim toga, zadruge broje čak 140 milijuna članova, time je svaki peti Europljanin član zadruge. ${ }^{12}$ Uzajamna društva, udruge i fondacije također su vrlo važni entiteti socijalne ekonomije koji ostvaruju značajne rezultate. No, u središtu interesa ovoga rada najviše su ipak društvena poduzeća (engl. social enterprises) koje Europska komisija definira kroz Inicijativu za društveno poslovanje kreirajući jedanaest koraka u cilju promocije i stvaranja povoljne klime ovih ključnih dionika. ${ }^{13}$ Daljnja je legislativna definicija društvenih poduzeća i pojma "socijalnih inovacija" predviđena u čl. 2 (1) i 2. (5) Uredbe (EU) o Programu Europske unije za zapošljavanje i socijalne inovacije. ${ }^{14}$ Uredba ide korak dalje navodeći "eksperimentiranje na području socijalne politike" u vidu "intervencije politike koja nudi inovativna rješenja za društvene potrebe."

Europski parlament doprinosi razvoju legislativnog okvira socijalne ekonomije nizom pisanih izjava te Odlukom ${ }^{15}$ kojom prepoznaje koncept društvenih poduzeća i daje prednost poslovnom modelu demokratskog pristupa te sudjelovanjem različitih dionika i ulaganjem najvećeg dijela profita u održivi razvoj. ${ }^{16}$ Konačno, Europski ekonomski i socijalni odbor (EESC) serijom usvojenih mišljenja i preporuka, doprinosi institucionalnom osnaženju ove propulzivne teme. Strasburška deklaracija je 2014. okupila više od 2000 društvenih poduzetnika, ${ }^{17}$ Milanska se deklaracija iste godine bavila važnošću socijalnih inovacija i socijalnih investicija te "neriješenim socijalnim pitanjima u postizanju društvenih i gospodarski promjena"18 te konačno Rimska strategija o potencijalima socijalne ekonomije Europe koja je u mnogim temama dotaknula i pitanja uključivanja aktera/društvenih poduzeća u javnu nabavu ne samo implementacijom tzv. socijalnih klauzula. ${ }^{19}$ Direktiva o javnoj nabavi ${ }^{20}$ predviđa rezervirane ugovore za društvena poduzeća i ostale organizacije socijalne ekonomije, zahtijevajući od tijela

11 Jurić, D., Europska zadruga, Pravo i porezi, 6/2006., str. 58.-67.: "Uredba o statutu Europske zadruge i Smjernicu o suodlučivanju radnika. Ovim propisima želio se uspostaviti jedinstveni pravni položaj zadruge na unutarnjem tržištu Unije pri ostvarenju onih gospodarskih djelatnosti kod kojih nije naglasak na ostvarivanju dobiti, već na promicanju zajedničkih interesa članova zadruge i društvene zajednice u kojoj djeluje. Zadruge su osobito pogodne za malo i srednje poduzetništvo."

12 Cooperatives Europe: The Power of cooperation - Cooperatives Europe key figures 2015. Brussels, 2016 https://coopseurope.coop/ sites/default/files/The\%20power\%20of\%20Cooperation\%20-\%20Cooperatives\%20Eu rope\%20key\%20statistics\%202015.pdf, pristupljeno 5. siječnja 2017.

13 European Commission - Social Business Initiative: Creating a favourable climate for social enterprises, key stakeholders in the social economy and innovation, Brussels, 2011. https://www.fi-compass.eu/sites/default/files/publications/social-businessinitiative-creating-a-favourable-climate-for-social-enterprises-key-stakeholders-in-the-social-economy-and-innovation.pdf.

14 Uredba (EU) br. 1296/2013 Europskog parlamenta i Vijeća od 11. prosinca 2013. o programu Europske unije za zapošljavanje i socijalne inovacije.

15 European Parliament resolution of 19 February 2009 on Social Economy (2008/2250(INI)) http://www.europarl.europa.eu/ sides/getDoc.do?pubRef=-//EP//TEXT+TA+P6-TA-2009-0062+0+DOC+XML+V0//EN.

16 Petričević, T., Zakonodavni i institucionalni okvir za razvoj društvenog poduzetništva u jugoistočnoj Europi, CEDRA, Čakovec, 2012., http://cedra.hr/assets/attach/posts/642/socentlegalsee-hr.pdf.

17 Strasburška deklaracija http://ec.europa.eu/internal-market/conferences/2014/0116-social-entrepreneurs/decla ration/indexen.htm, pristupljeno 15. prosinca. 2017.

18 Milanska deklaracija http: www.eesc.europa.eu/?i=portal.en.events-and-ACTivities-boosting-innovation-mil an-declaration, pristupljeno 10. prosinca 2017.

19 European Economic and Social Committee, Unlocking the Potential of the Social Economy for EU Growth: The Rome Strategy, 2014 http://socialeconomyrome.it/files/Rome\%20strategy-EN.pdf, pristupljeno 12. prosinca. 2016. 
javne vlasti da pri dodjeljivanju javnih natječaja uzmu u obzir (iako ne obvezu) društveno-socijalne i okolišne kriterije ponuđača.

\subsection{DRUŠTVENA PODUZEĆA U PRAVNOM PROSTORU DRŽAVA ČLANICA EU-A}

Države članice EU-a razlikuju socijalna poduzeća s obzirom na povijesnu, političku i tradicijsku uvjetovanost. Prema Izvješću Europske komisije ${ }^{21}$ primjeri zemalja s posebnim legislativnim uobličenjem za društvena poduzeća jesu Belgija, Francuska, Italija, Slovenija i Ujedinjena Kraljevina koja donekle korespondira s definicijom komisije iz SBI-ja; dok su zemlje poput Bugarske, Češke, Flamanske regije Belgije, Mađarske, Rumunjske, Slovačke i Poljske više okrenute WISE (Work Integration Social Enterprises) pristupu poduzeća koja se bave integriranjem posebnih skupina u radu pa je prihvaćanje koncepta tek započelo svoj proces formiranja uglavnom mogućnošću financiranja projekata preko fondova EU-a. Analiza ${ }^{22}$ socijalnih poduzeća za radnu integraciju u izabranim (post)tranzicijskim članicama EU-a pokazala je njihovo zaostajanje u razvoju koje se najviše očituje u nepostojećim izvorima financiranja, deficitarnim kompetencijama djelatnika te općenito preniskom razinu senzibilizacije šire javnosti o važnosti i vrijednostima tih poduzeća. Pritom je u svim segmentima zaostajanje Hrvatske posebno značajno.

Nepostojanje posebnog pravnog oblika društvenih poduzeća u nekim zemljama nije zapreka za postizanje ekonomskog učinka dok se druge zemlje susreću s mnogim barijerama postojećih pravnih oblika koja ne dopuštaju fleksibilnija pravila potrebna društvenim poduzećima u nastajanju. Uspješni su primjeri zemalja prve kategorije Belgija ${ }^{23}$ i Francuska. Te zemlje često pri provođenju društveno-poduzetničkih projekata koriste udruge (engl. associations) koje u njihovu pravnom sustavu nisu fiskalno opterećene dvostrukim nametima (kao što je slučaj $\mathrm{u} \mathrm{RH}$ ) - nego se mogu slobodno razvijati u ekonomskim aktivnostima i financirati vlastiti poslovni pothvat. Suprotno tome u zemljama gdje je ekonomska aktivnost udruga limitirana, ekonomski pothvati društvenih poduzeća najčešće se odvijaju preko zadružnih modela. Teškoće na koje nailaze njemački društveni poduzetnici ilustrira situacija najnovijeg Izvješća EFESIIS-a iz 2016 o novoj generaciji društvenih poduzetnika ${ }^{24}$ koji su često prisiljeni voditi se kompleksnim pravnim operacijama koristeći nekoliko pravnih modela odjedanput.

I prema području djelovanja postoje bitne razlike. U zemljama s jakom tradicijom socijalne skrbi i relativnim zadovoljenjem potreba stanovništva (Njemačka, Austrija, zemlje skandinavske regije) društvena poduzeća profiliraju se u posebnim nišama, najčešće tražeći neki inovativni pristup ili novu socijalnu uslugu koju će pružiti, dok s druge strane u zemljama

21 Europska komisija, Društvena poduzeća i njihov eko-sistem u Europi, Brisel, 2015 URL= https://ec.europa.eu /social/main.js p?catId=952\&intPageId=2914\&langId=en\#navItem-related, https://ec.europa.eu/social/Blob Servl t?docId=12987\&langId=en, pristupljeno, 17. veljače 2019.

22 Marković, L., Baturina, D., Babić, Z. Socijalna poduzeća za radnu integraciju (WISE) u postsocijalističkim zemljama, Hrvatska revija za rehabilitacijska istraživanja, vol. 53, br. 1, 2017., str. 139.-158. https://doi.org/10.31299/hrri.53.1.11.

23 Tipično belgijsko neprofitno društvo association sans but lucratif (ASBL) fleksibilno poduzima aktivnosti koje mu donose profitnu dobit i prihode pod uvjetom da se one naravno poduzimaju u skladu sa misijom društva.

24 EFESEIIS, New Generation Social Enterprises. Impact Hub GmbH, 2016. http://www.fp7-efeseiis.eu/new-generation-of-socialenterprises/. 
odmaknutim od tradicionalnog modela socijalne skrbi (Italija, Grčka, Portugal, Španjolska, Poljska i Irska) društvena poduzeća "amortiziraju” praznine u djelatnostima socijalne skrbi koje tijela javne vlasti više nisu u stanju vršiti adekvatno. Prakticiranje širokog obujma usluga od općeg interesa preko društvenih poduzeća vidljiv je i u Velikoj Britaniji, Francuskoj i Belgiji.

\subsection{MODELI I TRENDOVI DJELOVANJA DRUŠTVENIH PODUZEĆA U EU-U}

Prema Ficiju ${ }^{25}$ u Europi su danas na snazi tri modela: zadružni, privatni te onaj koji dopušta princip slobodnog izbora između postojećih pozitivnih normi. Zadružni model svoj začetak ima u talijanskim zadružnim pokretima devedesetih godina, vrlo je popularan u zemljama čija se tradicija i povijest zasniva na takvim trendovima: Portugal, Španjolska, Italija, Grčka, Francuska, Mađarska, Poljska, Hrvatska i Češka. Model zastupa demokratičnost i neovisnost upravljanja uz obaveznu otvorenost novim članovima, pa je stoga jasno zašto je privlačan i praktičan akterima društvenog poduzetništva. Primjeri uspješnosti zadruga u Europi i svije$\mathrm{tu}^{26}$ zauzimaju mnogo više pozornosti i prostora. Posebno valja istaknuti, uz talijanske regije Emilia Romagna, Toscana i Trentino te danske energetske zadruge, ${ }^{27}$ baskijskog diva Mondragon ${ }^{28}$ koji je već dugo jedan od vodećih zadružnih lidera na svijetu. Mondragon zapošljava 75.000 ljudi, okuplja 257 kooperanata i nakon 60 godina uspješno odgovara izazovima današnjeg tržišta. Participativni menadžment, fair udio u isplaćivanju dobiti i dijeljenju gubitaka na temelju ulagačkih udjela, povezani discipliniranim radom - sažeta su baza Mondragonove zadružne filozofije.

Društvena poduzeća u nešto drukčijoj formi, najbližoj privatnim kompanijama osuvremenjuje britanski CIC model kao i belgijski (société ŕ finalité sociale, SFS). To je poseban podtip privatnog poduzeća koje je u osnivačkim aktima jasno usmjereno prema širim društvenim ciljevima uz statutarno definiranje ograničenja profitne raspodjele. Ipak, ono nije (nužno) vođeno sudioničkim i demokratskim pravilima ${ }^{29}$ kao što je to slučaj kod zadružnih modela nego primarno privatnim interesima osnivača. Konačno, prisutan je i model slobodnog izbo$\mathrm{ra},{ }^{30}$ kao alternativa prethodnim trendovima, prema kojemu bilo koja forma društava osoba ili kapitala (postojećeg zakonodavstva zemlje članice) može biti funkcionalni pravni modus društvenog poduzeća.

Gledajući širu sliku, trendovi i izazovi društvenih poduzeća u Europi odnose se na sljedeće:

25 Fici, A., Recognition and Legal Forms of Social Enterprise in Europe: A Critical Analysis from Comparative Law Perspective. Euricse Working Papers, 82 |15, 2015. http://www.euricse.eu/wp-content/uploads/2015/12/WP-82-15-Fici2.pdf, pristupljeno 7. studenog 2018.

26 Prema Šimleša, D., Zeleni alati: dobra ekonomija, Zelena mreža aktivističkih grupa, Vukomerić, 2015. “U Brazilu sedam tisuća liječnika liječi ljude kroz zadrugu UNIMED... CO-op City Bronx, NY najveća je stambena zadruga na svijetu; u Keniji zadruge drže 70\% tržišta kavom i 95\% tržišta pamuka dok u Japanu najveća mreža potrošačkih zadruga broji 24 milijuna članova." Dvije tisuće energetskih zadruga sa 150.000 članova.

28 Mondragon, službena mrežna stranica http://www.mondragon-corporation.com/, pristupljeno 12. studenog 2016.

29 Belgijski SFS ima ograničenje dioničarskih glasačkih prava po svakom dioničaru (1/10). 
- Rastuću potražnju za uslugama općeg javnog interesa: Europa stari pa je u mnogim zapadnoeuropskim zemljama veliki interes usmjeren u područje skrbi i razvoja usluga za treću životnu dob. Koncept Silver Economy je sve relevantniji. ${ }^{31}$

- Potrebu za inovativnosti ${ }^{32}$ u područjima održivog razvoja. Kao suvremene primjere inovativnosti i socijalnih inovacija, Vidovićc ${ }^{33}$ navodi mikrofinanciranje, poštenu trgovinu (engl. fair trade), međunarodne standarde rada, društveno odgovorno investiranje te osobne razvojne račune. Prema Deesu ${ }^{34}$ inovacija može imati mnogo formi i ne mora nužno značiti smišljanje novoga već primjena postojeće ideje na nov način ili novu situaciju. Poduzetnici su tu da primjenjuju na kreativan način ono što su drugi već osmislili. Za društvene poduzetnike to je važno jer u svojoj socijalnoj misiji inoviraju neku novu uslugu, proizvod, program ili, kako Dees navodi, zadovoljavanje neke nezadovoljene društvene potrebe.

- Razvoj terminologije i pravnog usustavljivanja: Evolucija pravnih propisa kroz nacionalna zakonodavstva usuglašena s definicijom Social Business Initiative 2011 dovela je u najmanju ruku do razjašnjenja kriterija koje društvena poduzeća moraju utjelovljavati. Fici ${ }^{35}$ navodi da, iako se kamenom temeljcem europskog legislativnog začetka društvenog poduzetništva smatra talijanski zakon iz 1991., britanski je akt iz 1965. (Industrial and Provident Societies Act) prvi moderniji akt koji je otvorio mogućnost za društva čija se ekonomska aktivnost izražava u isključivoj zajedničkoj dobrobiti tzv. Community Benefit Society (Bencom). Baveći se područjem socijalnog privatnog prava, Fici naglašava dužnost i obavezu aktera DP-a da u svojem djelovanju koriste naziv društvenih poduzetnika iako kao hibridna poduzeća kombiniraju pravila privatnog prava s djelatnošću i načelima trećeg sektora. Taj je poseban interes i potreba pravne distinkcije definiran mnogim europskim zakonima o društvenim poduzećima ${ }^{36} \mathrm{i}$ argumentiran sljedećim razlozima:

1) kreiranjem posebne politike/javnih mjera u korist društvenih poduzeća

2) zaštiti različitih dionika društvenog poduzetništva (od kupaca i korisnika do investitora i dobavljača)

3) jasnijoj granici sa sličnim konceptima poput društveno odgovornog poslovanja.

31 European Commission, Silver Economy Study: How to stimulate the economy by hundreds of millions of Euros per year. 2018 https://ec.europa.eu/digital-single-market/en/news/silver-economy-study-how-stimulate-economy -hundreds-millions-eurosyear, pristupljeno 12. studenog 2018.

rijednost inovativnosti na visokoj je cijeni "Društvene inovacije jesu ideje koje su provedene uz praktičan pristup, koje su nove u kontekstu u kojem se pojavljuju i privlače nadu za boljim strategijama suočavanja i rješavanja te su označene visokim stupnjem rizika i neizvjesnosti. "Welfare innovations at the local level in favor of cohesion (WILCO) 2014, str. 2.; http:// www.wilcoproject. eu, pristupljeno 10. studenog 2018.

34 Levenson Keohane G., Social entrepreneurs for 21 century: Innovation Across the Nonprofit, Private, and Public Sectors. McGraw-Hill Education, 2013.

35 Fici, A., op. cit. u bilj. 27.

36 Fici (op. cit. u bilj. 27) navodi kako ekskluzivno pravo upotrebe termina "društveno poduzeće" u svojim nazivima predviđaju sljedeći zakoni: Talijanski legislativni dekret no. 155/2006; čl. 667, Belgijski zakonik društava kapitala (Company Code); čl. 2, st. 2, Finski zakon 1351/2003; čl. 18., st. 3, Slovenski zakon 20/2011; Češki zakon 90/2012, čl. 759). 
- Visoku svijest o proizvodima i uslugama dodane vrijednosti. Cijena, kvaliteta i porijeklo proizvoda, okolišne vrijednosti te izbor fair trade poslovanja ključni su faktor koji sve više prepoznaje današnji. Stoga takva dodana vrijednost svakako ide u prilog otvaranju novim tržištima za društvena poduzeća.

- Poboljšanje novih vještina menadžmenta za kojima generalno vapi sektor društvenog poduzetništva jer bi "menadžerski alati trebali omogućiti društvenim poduzećima da postanu više poduzetnička osim samo sposobna za dobivanje subvencija".

- Uključivanje ili barem lobiranje za uključivanje društvenih poduzeća u procese javne nabave kao i korištenje "socijalnih klauzula" i "rezerviranih ugovora". Što se tiče novih članica EU-a i njihova društveno poduzetničkog eko sustava, najveće slabosti koje Deforney ${ }^{37}$ prepoznaje u odnosu na zapadnoeuropske zemlje članice jest nedovoljno prepoznavanje vrijednosti alternativnih organizacija (trećeg sektora), potom jak otpor prema zadružnim vrijednostima i potencijalnoj dobrobiti uvjetovan lošim povijesnim iskustvima i pretjeranu ovisnost o sustavu grantova EU-a.

Zaključno, normiranje DP-a u Europi trenutačno je kontradiktorno područje jer se s jedne strane želi pojačati pravna prepoznatljivost društvenih poduzeća kako bi ista mogla ravnopravno nastupati na tržištu, biti što konkurentnija i pravno sigurna, šaljući tako signal potencijalnim ulagačima i korisnicima. S druge strane i dalje se u pokušajima reguliranja ostavlja relativno prazan prostor (neprepoznavanja mnogih vrijednih aktera i djelatnosti) pri vršenju važnih uloga pružanja usluga javnog interesa u kojima većina država više ne može dati adekvatan odgovor. Konačno, zbog razvoja ovog fenomena javlja se potreba jasne distinkcije između različitih smjerova društvenog poduzetništva koje ne mora isključivo ${ }^{38}$ biti usmjereno na socijalnu inkluziju ugroženih skupina nego i održivo poduzetničko djelovanje usmjereno na šire društvene ciljeve (kulturne, inovacijske i okolišne) koje ipak nisu u domeni profitnog sektora ili javne uprave. Ta je praznina ujedno prilika koju valja iskoristiti kao priliku za inovativno, kvalitetno i svjesnije doba novih mogućnosti ekonomije u kojima se Europa trenutačno traži. Tablica 2 komparativno predstavlja pregled zakonodavnog okvira i prihvaćenosti društvenog poduzetništva u izabranim državama članicama. 
Tablica 2. Komparativni prikaz normativnog okvira u EU-u

\begin{tabular}{|c|c|c|c|}
\hline $\begin{array}{c}\text { ZEMLJA } \\
\text { ČLANICA EU-a }\end{array}$ & $\begin{array}{c}\text { PRIHVAĆENOST } \\
\text { KONCEPTA } \\
\text { DRUŠTVENOG } \\
\text { PODUZETNIŠTVA }\end{array}$ & $\begin{array}{l}\text { OBLICI DRUŠTVENIH } \\
\text { PODUZEĆA }\end{array}$ & ZAKONODAVNI OKVIR \\
\hline Njemačka & \begin{tabular}{|l|} 
Ne poznaje unificiranu \\
definiciju društvenog \\
poduzetništva. \\
Društveni poduzetnici \\
su definirani kao "akteri \\
koji osnivaju društvena \\
poduzeća i organizacije \\
individualnim građan- \\
skim angažmanom kako \\
bi adresirali postojeće \\
socijalne potrebe i izazove \\
s inovativnim poduzet- \\
ničkim pristupom". Jak \\
utjecaj angloameričkog \\
change-maker pristupa \\
koji zastupa Ashtoka. \\
\end{tabular} & $\begin{array}{l}\text { Dugu tradiciju soc. } \\
\text { ekonomije. } \\
\text { Nemaju poseban zako- } \\
\text { nom predviđen oblik, } \\
\text { koriste različite pravne } \\
\text { forme, a najčešće statuse } \\
\text { ograničene odgovornosti } \\
\text { (GmbH). } \\
\text { Nosioci su određenih } \\
\text { javnih pogodnosti koje } \\
\text { uključuju posebne pore- } \\
\text { zne i fiskalne olakšice. }\end{array}$ & $\begin{array}{l}\text { Funkcioniraju prema po- } \\
\text { stojećem zakonodavnom } \\
\text { okviru i nemaju posebnih } \\
\text { zakonodavnih odredbi } \\
\text { koje se tiču društvenog } \\
\text { poduzetništva. } \\
\text { Godine 2013. uveden } \\
\text { status društva s ogra- } \\
\text { ničenom odgovornošću } \\
\text { sa socijalnom misijom } \\
\text { (gGmbH), i dalje pod pra- } \\
\text { vom trgovačkih društava } \\
\text { - oblik koji mora ispuniti } \\
\text { brojne uvjete koji uključu- } \\
\text { ju i neprofitnu svrhu. }\end{array}$ \\
\hline Francuska & $\begin{array}{l}\text { Koncept označava inici- } \\
\text { jative privatno-javnog } \\
\text { partnerstva sa socijalnim } \\
\text { ciljem, profitne inicijative } \\
\text { koje uključuju socijalne } \\
\text { inovacije ili pak sve te } \\
\text { aktivnosti ujedinjene pod } \\
\text { nazivom "društvena od- } \\
\text { govornost poduzeća"(R- } \\
\text { SE) koji je vrlo uspješan u } \\
\text { zemlji. } \\
\text { Lex generalis: Zakon o so- } \\
\text { cijalnoj i solidarno ekono- } \\
\text { miji (2014) regulira pojam } \\
\text { društvene ekonomije. }\end{array}$ & $\begin{array}{l}\text { Zadruge, } \\
\text { uzajamna društva i } \\
\text { fondacije } \\
\text { uključene u ekonomsku } \\
\text { aktivnost ne slijede } \\
\text { posebnu proceduru ili } \\
\text { uvjete. }\end{array}$ & $\begin{array}{l}\text { Zakon o socijalnoj i soli- } \\
\text { darnoj ekonomiji ( Eco- } \\
\text { nomie sociale et solidarie), } \\
\text { izglasan } 2014 \text {. s ključnim } \\
\text { naglascima na priznanje } \\
\text { solidarne ekonomije, } \\
\text { osnaživanje umrežavanja } \\
\text { entiteta, pravodobno } \\
\text { informiranje radnika o } \\
\text { stanju poslovanja, lokal- } \\
\text { noj javnoj inicijativi u } \\
\text { razvoju sektora. } \\
\text { Zakon o društvima od } \\
\text { javnog interesa iz 2001. } \\
\text { (Société coopérative d'In- } \\
\text { térêt Collectif) -zadružna } \\
\text { društva od javnog inte- } \\
\text { resa nova pravna forma. } \\
\text { Članstvo mora uključivati } \\
\text { radnike i korisnike, a } \\
\text { predviđene su tzv. odred- } \\
\text { be asset locka. }\end{array}$ \\
\hline
\end{tabular}




\begin{tabular}{|c|c|c|c|}
\hline Belgija & $\begin{array}{l}\text { Pojam je prepoznat } 2008 . \\
\text { uvođenjem raznih mi- } \\
\text { nistarstava koja se bave } \\
\text { kreiranjem regionalne } \\
\text { politike razvoja. Društve- } \\
\text { na poduzeća i aktivnosti } \\
\text { pod utjecajem su WISE } \\
\text { definicije i bave se radnom } \\
\text { integracijom osoba u ne- } \\
\text { povoljnijem položaju. }\end{array}$ & $\begin{array}{l}\text { Tzv. poduzeća sa socijal- } \\
\text { nom svrhom - ispunja- } \\
\text { vaju Statutom određene } \\
\text { društvene ciljeve. Gla- } \\
\text { sačka prava moguća po- } \\
\text { sjedovanjem min. } 1 / 10 \\
\text { predstavničkih } \\
\text { dionica. }\end{array}$ & $\begin{array}{l}\text { Brojni su regionalni de- } \\
\text { kreti iz 1990-ih kojima } \\
\text { se podržava razvoj WISE } \\
\text {-poduzeća i zapošljavanje } \\
\text { ranjivih skupina. }\end{array}$ \\
\hline Poljska & $\begin{array}{l}\text { Društvena poduzeća pre- } \\
\text { poznata prvi put } 2003 . \\
\text { Aktom o socijalnom } \\
\text { zapošljavanju. }\end{array}$ & $\begin{array}{l}\text { Najpopularniji oblici } \\
\text { društvenih poduzeća: } \\
\text { zadruge, socijalne zadru- } \\
\text { ge, uzajamna društva, } \\
\text { udruge, fondacije i centri } \\
\text { za socijalnu integraciju } \\
\text { - jedinice za aktivaciju } \\
\text { zapošljavanja fizički i } \\
\text { mentalno ograničenih } \\
\text { osoba. }\end{array}$ & $\begin{array}{l}\text { Zakon o javnoj dobrobiti } \\
\text { i volonterskom radu iz } \\
\text { 2003.; prvi Zakon o so- } \\
\text { cijalnom zapošljavanju } \\
\text { (2003), Zakon o udruga- } \\
\text { ma i fondovima, Zakon o } \\
\text { profesionalnim centrima } \\
\text { aktivacije i Zakon o so- } \\
\text { cijalnim zadrugama iz } \\
\text { 2006. Zapošljavaju osobe } \\
\text { s posebnim potrebama } \\
\text { integrirajući ih preko rada } \\
\text { a da su pritom obvezane } \\
\text { zapošljavati najmanje } \\
\text { 50\% osoba s posebnim } \\
\text { potrebama. }\end{array}$ \\
\hline Slovačka & $\begin{array}{l}\text { Prepoznaju društvena } \\
\text { poduzeća prvi put tzv. } \\
\text { Slovačkim pravnim ak- } \\
\text { tom 2008. Kvalifikacija } \\
\text { društvenih poduzeća } \\
\text { uglavnom vezana uz } \\
\text { WISE kvalifikaciju radne } \\
\text { integracije. }\end{array}$ & $\begin{array}{l}\text { Najpopularniji oblici } \\
\text { društvenih poduzeća: } \\
\text { zadruge, socijalne zadru- } \\
\text { ge, uzajamna društva, } \\
\text { udruge i } \\
\text { fondacije. }\end{array}$ & $\begin{array}{l}\text { Nacionalna Strategija za } \\
\text { razvoj socijalne ekonomi- } \\
\text { je } 2015 ., \text { Slovački legalni } \\
\text { akt } 2008 \text {. kojim prepo- } \\
\text { znaju društvena poduzeća } \\
\text { te kojim se dopunjuje } \\
\text { Zakon 5/2004 o službi } \\
\text { za zapošljavanje uvodi } \\
\text { kvalifikaciju društvenih } \\
\text { poduzeća koja može djelo- } \\
\text { vati pod bilo kojim prav- } \\
\text { nim oblikom, uvjetovano } \\
\text { zapošljavanjem osoba u } \\
\text { nepovoljnom položaju } \\
\text { i reinvestiranjem } 30 \% \\
\text { profita u novi proizvodni } \\
\text { ciklus. }\end{array}$ \\
\hline
\end{tabular}




\begin{tabular}{|c|c|c|c|}
\hline Švedska & $\begin{array}{l}\text { Društvena poduzeća s } \\
\text { ciljem integriranja margi- } \\
\text { naliziranih skupina ljudi } \\
\text { na tržištu rada definirana } \\
\text { kao radno integrirajuća } \\
\text { socijalna poduzeća (ar- } \\
\text { betsintegrerande sociala } \\
\text { företag), posebice od } \\
\text { strane vladinih tijela } \\
\text { koji financijski podupiru } \\
\text { WISE start-upove. }\end{array}$ & $\begin{array}{l}\text { Joint-stock kompanije } \\
\text { (Aktiebolag), zadružne } \\
\text { ekonomske asocijacije } \\
\text { (Ekonomiska förenin- } \\
\text { gar) trgovačka društva } \\
\text { (Handelsbolag). }\end{array}$ & $\begin{array}{l}\text { Zakon o slobodi izbora } \\
\text { (Lagen Om Valfrihet, } \\
\text { LOV). Pravo građana da } \\
\text { izabiru pružatelja usluga } \\
\text { socijalne skrbi (koji ulaze } \\
\text { i društvena poduzeća), } \\
\text { Akcijski plan za privat- } \\
\text { ni i neprofitni sektor } \\
\text { N2010/1894/ENT. }\end{array}$ \\
\hline Finska & $\begin{array}{l}\text { Akt o socijalnim poduzeći- } \\
\text { ma/ Act on Social Enter- } \\
\text { prise (1351/2003) koji } \\
\text { ograničava poduzeća na } \\
\text { polje radne integracije. }\end{array}$ & Većinom WISE pristup. & $\begin{array}{l}\text { Akt o socijalnim } \\
\text { poduzećima1351/2003. }\end{array}$ \\
\hline Italija & $\begin{array}{l}\text { Ustavno priznanje so- } \\
\text { cijalne ekonomije uz } \\
\text { priznanje prave kategorije } \\
\text { Impresa sociale } \\
\text { Zakon } 155 / 2006 \text { o socijal- } \\
\text { nim poduzećima. }\end{array}$ & $\begin{array}{l}\text { Neprofitne organizacije } \\
\text { za socijalne ciljeve tzv. } \\
\text { ONULUS. } \\
\text { Zadruge (korisničke, } \\
\text { proizvodne i radne, agri- } \\
\text { kulturne, udomiteljske, } \\
\text { stambene, ribarske, mije- } \\
\text { šane, socijalne). } \\
\text { Udruge } \\
\text { Društvena poduzeća - } \\
\text { Impresa Sociale. }\end{array}$ & $\begin{array}{l}\text { Zakon 381/1991 o soci- } \\
\text { jalnim zadrugama, Zakon } \\
\text { 155/2006 o društvenim } \\
\text { poduzećima, Zakon } \\
\text { 106/2016 o reformi tre- } \\
\text { ćeg sektora; čl. } 6 \text { odnosi } \\
\text { se na poboljšanje pravnog } \\
\text { statusa društvenih podu- } \\
\text { zeća Zakon 142. i } 241 . \text { iz } \\
\text { 1990. modaliteti u kojim } \\
\text { lokalna javna uprava } \\
\text { unutar vlastite nadležno- } \\
\text { sti upravlja djelatnošću } \\
\text { socijalne skrbi. }\end{array}$ \\
\hline Španjolska & $\begin{array}{l}\text { Ustav iz 1978. referira se } \\
\text { u općem i posebnom dije- } \\
\text { lu na socijalnu ekonomiju } \\
\text { u čl.1/9, 34/40/129. } \\
\text { Zakoni kojima se regulira } \\
\text { postojanje i djelovanje } \\
\text { društvenih poduzeća } \\
\text { uglavnom se bave rad- } \\
\text { nom integracijom/WISE } \\
\text { kvalifikacija. }\end{array}$ & $\begin{array}{l}\text { Uz postojeće klasične } \\
\text { organizacije socijalne } \\
\text { ekonomije udruge, } \\
\text { zadruge i fondacije na- } \\
\text { jvažniji institucionalni } \\
\text { oblici jesu neprofitna } \\
\text { društva uzajamne koris- } \\
\text { ti, društva u vlasništvu } \\
\text { radnika vrsta društvenog } \\
\text { poduzeća s visokim po- } \\
\text { tencijalom za poslovanje, } \\
\text { gdje se glavnina kapitala } \\
\text { dijeli između zaposleni- } \\
\text { ka, razni oblici sigurnih } \\
\text { kuća i utočišta, centri za } \\
\text { zapošljavanje, agrikultur- } \\
\text { na i ribarska društvima. }\end{array}$ & $\begin{array}{l}\text { Zakon } 27 / 1999 \text { o za- } \\
\text { drugama socijalne } \\
\text { inicijative: ekonomska } \\
\text { aktivnost usmjerena na } \\
\text { zapošljavanje socijalno } \\
\text { isključenih, predviđa } \\
\text { dioničare radnike i zapos- } \\
\text { lenike. Zakon 44/2007 } \\
\text { o socijalnoj integraciji } \\
\text { prati WISE definiciju } \\
\text { društvenih poduzeća; } \\
\text { Zakon 5/2011 (konomia } \\
\text { Social) - entiteti socijalne } \\
\text { ekonomije djeluju unutar } \\
\text { postojećeg zakonodavnog } \\
\text { okvira. }\end{array}$ \\
\hline
\end{tabular}




\begin{tabular}{|c|c|c|c|}
\hline Velika Britanija & $\begin{array}{l}\text { Društvena poduzeća: } \\
\text { Community Interest } \\
\text { Company (CIC) Regulations } \\
2005 .\end{array}$ & $\begin{array}{l}\text { Dionička društva - } \\
\text { Company limited by } \\
\text { shares (CLS); društva s } \\
\text { ograničenom odgovor- } \\
\text { nošću - Company limited } \\
\text { by Guarantee (CLG); } \\
\text { poduzeća sa zajedničkim } \\
\text { interesom - Community } \\
\text { Interest Company (CIC) } \\
\text { Industrial and Provident } \\
\text { Societies (IPS); } \\
\text { dobrotvorna društva } \\
\text { trgovci pojedinci - Sole } \\
\text { trader i partnerstva } \\
\text { Partnership. }\end{array}$ & $\begin{array}{l}\text { Public Service Social Va- } \\
\text { lue Act } 2013 \\
\text { Finance Bill - porezne } \\
\text { olakšice na socijalne } \\
\text { investicije. } \\
\text { Community Interest } \\
\text { Company Regulations } \\
2005 .\end{array}$ \\
\hline
\end{tabular}

Izvor: prilagođeno prema European Commission, A map of social enterprises and their eco-systems in Europe, 2015, https://ec.europa.eu/social/BlobServlet?docId=12987\&langId=en, pristupljeno 5. studenog 2018.

\section{HRVATSKA - PRAVNI OKVIR ZA RAZVOJ DRUŠTVENIH PODUZEĆA}

Društveno je poduzetništvo u RH najviše prisutno tijekom posljednja dva desetljeća u civilnom sektoru, kroz djelatnost udruga, inicijatora različitih oblika društvene ekonomije u Hrvatskoj te asimiliranjem ideja brojnih međunarodnih ${ }^{39}$ organizacija. Do 2015. u upotrebi se često koristio termin "socijalno poduzetništvo", a donošenjem Strategije usvojen je termin "društveno poduzetništvo" kako bi se ovakvim inicijativama dala vidljivost i omogućilo pomicanje konteksta radne integracije ili pružanja socijalnih usluga. No postoje mišljenja ispitanika ${ }^{40}$ kako bi termin "društvena ekonomija” možda bio najprimjereniji krovni pojam jer uključuje sve aktere trećeg sektora.

Izvještaj o stanju društvenog poduzetništva ${ }^{41}$ kronološki ocrtava put i razvoj društvenog poduzetništva u posljednja dva desetljeća: tako navodi podatak da se prvo spominjanje koncepta (neprofitno poduzetništvo) pojavljuje u radu profesora Gojka Bežovana u Reviji za socijalnu politiku 1996.; prvo navođenje termina socijalnog poduzetništvo (koje je danas preimenovano u društveno) u strateškom državnom dokumentu iz 2007.;2 prvo društveno poduzeće u Hrvatskoj osniva se 2008. kada je čakovečka udruga Autonomni centar ACT ${ }^{43}$ osnovala vla-

39 Organizacije poput NESsTa, (Nonprofit Enterprize and Self Sustainability Team) AED (Akademija za razvoj edukacije) i USAID (Američka agencija za međunarodni razvoj).

40 Dr. sc. Dražen Šimleša, društveni aktivist, sociolog i znanstvenik na Institutu Ivo Pilar; voditelj Centra za istraživanje integralne održivosti i održivog razvoja.

41 Šimleša, D., Puđak, J., Majetić, F., Bušljeta Tonković, A., Mapiranje novih obzora: Izvještaj o stanju društvenog poduzetništva u Hrvatskoj, Institut Ivo Pilar, Zagreb, 2015.

42 Vlada RH, Nacionalna strategija stvaranje poticajnog okruženja za razvoj civilnog društva 2006.-2011., Zagreb, 2007.

43 Detaljno o ACT grupi: Stubbs, P., Vidović, D., Social Enterprise in Transition: A Case Study of ACT Group, Društvena istraživanja, vol. 26, br. 2, 2017., str. 143.-163., https://doi.org/10.5559/di.26.2.01. 
stito društveno poduzeće za grafički i web dizajn ACT Printlab d.o.o., a Udruga Roda prva započela s inovativnim društveno-poduzetničkim projektom proizvodnje platnenih pelena kao NESsT $^{44}$ poduzeće 2007. Prevladavajuća je ocjena ${ }^{45}$ da je društveno poduzetništvo u Hrvatskoj još u povojima te da je, za razliku od Europe, u RH zanemaren njegov potencijal te se osim izdvojenih primjera dobre prakse ne može govoriti o sustavnoj podršci i uspjesima. Stoga je moguće da Hrvatska propusti prilike pogodnog trenutka ekspanzije društvenog poduzetništva.

Socijalna zadruga prvi put je prepoznata kao mogući akter društvenog poduzetništva novim Zakonom o zadrugama (Narodne novine, broj 34/2011) u modelu radne integracije i uključivanja u ekonomske aktivnosti "osoba s umanjenom radnom sposobnošću i drugih fizičkih osoba koje nemaju dovoljno sredstava za podmirenje osnovnih životnih potreba" ${ }^{46} \mathrm{U}$ Strategiji borbe protiv siromaštva i socijalne isključenost 2014.-2020. spominje se društveno poduzetništvo kao aktivnost povećanja zaposlenosti i smanjenja regionalnih razlika, a Vlada 2015. donosi Strategiju razvoja društvenog poduzetništva za razdoblje od 2015 do 2020. dajući društvenom poduzetništvu vidljivost preko temeljnog akta koji bi jasno navedenim mjerama razvoja trebao upravljati procesima društvenog poduzetništva na nacionalnoj razini. Bitno je napomenuti da nijedna od ključne četiri mjere još nije konkretizirana. Mjere su navedene kao uspostava i unaprjeđenje zakonodavnog i institucionalnog okvira; uspostava financijskog okvira; promicanje obrazovanja za društveno poduzetništvo te osiguranje vidljivosti društvenog poduzetništva. Baturina ${ }^{47}$ dodatno upozorava na pretjerano optimistične ciljeve Strategije te na činjenicu da razvojem sektora dominantno upravlja država dok u javnoj upravi postoji manjak osviještenosti o društvenom poduzetništvu i značajan deficit horizontalne i vertikalne koordinacije.

\subsection{TEMELJNE NAMJERE NACIONALNE STRATEGIJE}

Strategija će društveno poduzetništvo definirati kao: "Poslovanje temeljeno na načelima društvene, okolišne i ekonomske održivosti, kod kojeg se stvorena dobit/višak prihoda u cijelosti ili većim dijelom ulaže za dobrobit zajednice." Zanimljivo je da Strategija za nositelja društveno poduzetničke aktivnosti koristi termin društvenog poduzetnika, a ne društvenih poduzeća (kao što je primjer talijanskih Impresa Sociale). Što se tiče kriterija prepoznavanja društvenih poduzetnika, radna skupina ove Strategije utvrdila ih je devet, no ovdje iznosimo samo najvažnije. Riječ je o bilo kojoj fizičkoj ili pravnoj osobi (osim RH ili tijela javne vlasti na lokalnoj i regionalnoj razini koja ne mogu isključivo djelovati kao društveni poduzetnici) koja obavlja djelatnost proizvodnje i prometa roba, pružanja usluga ili obavljanja umjetničke djelatnost i na način koji je povoljan za okoliš, unaprjeđivanje razvoja lokalne zajednice i društva u cjelini. Novu vrijednost stvara na način da u trogodišnjem razdoblju poslovanja poduzet-

44 NESsT http://www.nesst.org/, pristupljeno 10. prosinca 2016.

45 Vincetić, Vlatka et al., Definiranje područja i potencijal razvoja socijalnog poduzetništva Hrvatske u komparativnom kontekstu, Ekonomski pregled, vol. 64, br. 3, 2013, str. 256.-278., https://hrcak.srce.hr/105517.

46 Zakon o zadrugama (Narodne novine, broj 34/2011) čl. 66.

47 Baturina, D., A Critical Review of the First Strategy for the Development of Social Entrepreneurship in the Republic of Croatia 2015-2020 and potential for the development of the sector, Hrvatska i komparativna javna uprava, Poseban prilog uz br. 2/2018, 2018., str. 11.-38. 
ničkim djelovanjem ostvaruje najmanje $25 \%$ godišnjeg prihoda, dok minimalno $75 \%$ godišnje dobiti ulaže u ostvarivanje i razvoj ciljeva poslovanja. U proces donošenja odluka društveni poduzetnik obuhvaća sve ključne dionike ${ }^{48}$ navedene poslovne aktivnosti prema participativnim i demokratskim principima ${ }^{49}$ pri čemu vlasnički ili članski udjeli nisu isključiv kriterij glasačkih prava, a u slučaju završetka obavljanja djelatnosti općim osnivačkim aktom obavezuje se na prijenos imovine ${ }^{50} \mathrm{u}$ vlasništvo drugog društvenog poduzetnika s istim ili sličnim ciljevima poslovanja. Ispunjavanje svih navedenih kriterija, društveni poduzetnik trebao bi dokazati svojim aktima osnivanja pri podnošenju zahtjeva za upis u Evidenciju društvenih poduzetnika. Riječ je o službenom popisu društvenih poduzetnika u RH koje bi trebalo služiti uvođenju reda u redove društvenih poduzetnika.

Opći cilj Strategije naveden je kao "uspostava poticajnog okruženja za promicanje i razvoj društvenog poduzetništva u Republici Hrvatskoj” što bi prema mišljenju ispitanika trebalo značiti zdraviji ekosustav u vidu konkretnih mjera fiskalne politike (poreznih olakšica prije svega), poticajnih mjera javnih vlasti, postojanja investicijskog kapitala spremnog ulagati u društveno poduzetničke pothvate te otvorenijeg pristupa u praksi javne nabave. Zakonski okvir za djelovanje društvenih poduzeća u Republici Hrvatskoj omogućen je odredbama postojećeg pozitivnog zakonodavstva; iako ne i posebnim zakonom lex specialis. Od najvećeg značaja za sektor društvenog poduzetništva, Strategijom ${ }^{51}$ su navedeni sljedeći propisi: Zakon o zadrugama (Narodne novine, broj 34/2011, 125/2013, 76/2014), Zakon o udrugama (Narodne novine, broj 74/2014), Zakon o zakladama i fondacijama (Narodne novine, broj 36/1995, 64/2001), Zakon o ustanovama (Narodne novine, broj 76/1993, 29/1997, 47/1999, 35/2008), Zakon o trgovačkim društvima (Narodne novine, broj 152/2011, 111/2012), Zakon o profesionalnoj rehabilitaciji i zapošljavanju osoba s invaliditetom (Narodne novine, broj 143/2002, 33/2005, 157/2013), Zakon o javnoj nabavi (Narodne novine, broj 120/2016) i Zakon o poticanju razvoja malog gospodarstva (Narodne novine, broj 29/2002, 63/2007, 53/2012, 56/2013). Tablica 3 prikazuje glavne nalaze SWOT analize društvenog poduzetništva u RH koje se temelje na navedenim zakonima i drugim sekundarnim izvorima te intervjuima s ključnim akterima.

48 Radnike, članove, korisnike ili potrošače te suradničke organizacije.

49 Zadružni principi i načela.

50 Nakon pokrića obveza prema vjerovnicima i pokrića gubitka iz prethodnog razdoblja.

51 Strategija razvoja društvenog poduzetništva u Republici Hrvatskoj za razdoblje od 2015. do 2020. 


\section{Tablica 3. SWOT analiza društvenog poduzetništva u Hrvatskoj}

\begin{tabular}{|c|c|}
\hline Snage & Slabosti \\
\hline $\begin{array}{l}\text { - } \text { motivirani pojedinci i timovi } \\
\text { broj sve više raste } \\
\text { - pristup fondovima EU-a } \\
\text { - bogata zadružna tradicija i veliki zadružni potencijal } \\
\text { RH } \\
\text { - rastuća otvorenost edukacijskih programa visokog škol- } \\
\text { stva trendovima i strujama ekonomije trećeg sektora } \\
\text { - donošenje nacionalne Strategije - Vlada RH prepozna- } \\
\text { je značaj društvenog poduzetništva te 2015. u Saboru } \\
\text { izglasava zasad najviši nacionalni akt koji definira cilje- } \\
\text { ve i mjere do 2020. g. } \\
\text { - postojanje inicijativa, umrežavanja i platformi za po- } \\
\text { dršku i razmjenu ideja (ZMAG, Platforma za dobru } \\
\text { ekonomiju, Cedra, Lagovi, Hrvatska mreža za ruralni } \\
\text { razvoj, Hub Impact Zagreb) } \\
\text { - ukorjenjivanje koncepta i primjeri dobre prakse: Hu- } \\
\text { mana Nova, RODA, Act Print Lab, Slap, Zadruga za } \\
\text { etično financiranje - ZEF, Zelena energetska zadruga } \\
\text { - ZEZ itd. }\end{array}$ & $\begin{array}{l}\text { - slaba vidljivost društveno-poduzetničkog koncepta na } \\
\text { javnoj, lokalnoj i regionalnoj razini } \\
\text { - nepodržavajući normativni okvir: neodgovarajuće nor- } \\
\text { me unutar kojih društvena poduzeća funkcioniraju } \\
\text { - pravna neprilagođenost potrebama društvenog po- } \\
\text { duzetništva doprinosi traženju novih zakonodavnih } \\
\text { "rupa" ili odustajanja aktera od postojećih projekata } \\
\text { - slabosti javne nabave: potreba otvaranja društvenim } \\
\text { poduzetnicima i jačanje transparentnosti } \\
\text { - nepostojanje tržišta "socijalnog kapitala" - financijski } \\
\text { instrumenti, potencijalni privatni ulagači i kreditiranje } \\
\text { pod povoljnijim uvjetima } \\
\text { - niska razina menadžerskih i poduzetničkih znanja i vje- } \\
\text { ština postojećih aktera civilnog sektora } \\
\text { - ovisnost udruga i civilnog sektora o fondovima i natje- } \\
\text { čajima EU-a } \\
\text { - nepostojanje sustava markiranja proizvoda i usluga } \\
\text { - slaba iskorištenost eko-poljoprivrednih potencijala (za } \\
\text { proizvodnju ekoloških proizvoda u Hrvatskoj koristi se } \\
\text { samo 0,6\% poljoprivrednih površina) } \\
\text { - neprovođenje mjera iz Strategije razvoja. }\end{array}$ \\
\hline Prilike & Prijetnje \\
\hline $\begin{array}{l}\text { - iznimno povoljan zemljopisni položaj i očuvanost pri- } \\
\text { rodnih resursa koji pogoduje novim sektorima druš- } \\
\text { tvenog poduzetništva: energetika, eko poljoprivreda, } \\
\text { agroturizam } \\
\text { - usmjeravanje prema novim sektorima proizvodnje i } \\
\text { usluga visoke dodane vrijednosti i korištenje predno- } \\
\text { sti energetskog sektora, eko-agroturizama, kulturnog } \\
\text { turizma, edukacije i socijalnog turizma } \\
\text { - uključivanje domaćih velikih kompanija u pojedine po- } \\
\text { zitivne procese razvoja društvenog poduzetništva } \\
\text { - nastavak otvaranja institucija obrazovanja na svim ra- } \\
\text { zinama novim programima društveno poduzetničkih } \\
\text { vrijednosti i vještina } \\
\text { - razvoj PR aktivnosti društvenog poduzetništva } \\
\text { postojećih modela } \\
\text { - snažniji razvoj eko poljoprivrede i okretanje potencija- } \\
\text { lima zemlje i biodinamičke proizvodnje } \\
\text { - umrežavanje i povezivanje društvenih poduzetnika u } \\
\text { nacionalnu mrežu } \\
\text { - počeci umrežavanja proizvoda s dodanom vrijednošću } \\
\text { (www.održivi-proizvodi.hr) } \\
\text { - podizanje osviještenosti građana: biranje proizvoda i } \\
\text { usluga više dodane vrijednosti (ekoloških proizvoda } \\
\text { OPG-ova, proizvoda socijalnih zadruga) te općenito } \\
\text { osvještavanje lokalnih snaga i potrebe umrežavanja i } \\
\text { zajedništva. }\end{array}$ & $\begin{array}{l}\text { - neprepoznavanje vrijednosti rada, korisnosti i inicijati- } \\
\text { va postojećih aktera društvenog poduzetništva } \\
\text { - administrativne zapreke } \\
\text { - zloupotreba društveno poduzetničkog koncepta u cilju } \\
\text { korištenja sredstava iz EU-ovih fondova } \\
\text { - visoka razina korupcija koja se reflektira i na sustav } \\
\text { javne nabave } \\
\text { - podlijeganje stanju apatije, istrošenosti i kulturi straha } \\
\text { i nemoći } \\
\text { - iseljavanje stanovnika iz ruralnih područja (potencijal } \\
\text { za eko poljoprivredu i područja) } \\
\text { - iseljavanje visokoobrazovanog stanovništva. }\end{array}$ \\
\hline
\end{tabular}


Element ljudskog potencijala; osviještenih mladih, inovativnih i stručnih ljudi najznačajnija je prilika i snažan motor unatoč suvremenim silama teže koji postojeći ljudski pokretački kapital još snažnije modeliraju i potiču na djelovanje. Početke i motive domaćeg društvenog poduzetništva ispitanici uglavnom pripisuju radu udruga i civilnog sektora:

"Društvena poduzeća u domaćim okvirima iznikla su više-manje iz rada nekih udruga. Kod nas uglavnom cijeli sektor drže udruge jer žele potaknuti neke pozitivne promjene u zajednici u kojoj djeluju i uz to postati samoodrživi, zarađivati kroz to što rade te reinvestirati viškove u ostvarenje svoje misije... Iako je društveno poduzetništvo kod nas tek u začecima vidim perspektivu u DP-u kao potencijalno rješenje za nekolicinu društvenih i ekoloških problema..." 52

Članstvo u EU-u pogoduje razvoju domaćeg društvenog poduzetništva zbog dužnosti uređenja pravnog prostora u vidu harmoniziranja postojećih normi, zbog dostupnosti značajnih sredstava namijenjenih akterima socijalne ekonomije ${ }^{53}$ te zbog velikih mogućnosti učenja i razmjene prakse i znanja. Sve to generira prostor visokih kriterija pri kreiranju inovativnih projekata organizacija i pojedinca te obvezu poštene i jasne upotrebe sredstava dobivenih fondovima, a to kao temeljnu kvalitetu naglašavaju intervjuirani ispitanici:

“Trenutno je društveno poduzetništvo u Europi IN tema i bit će tako u narednih dvadesetak godina (...) Europski socijalni fond ima puno sredstva za društveno poduzetništvo što treba kvalitetno iskoristiti." 54

Na snažan financijski zamah koji dolazi iz fondova EU-a nadovezuje se glavna slabost civilnog sektora, a to je da u svojim društveno-poduzetničkim aktivnostima što manje ovise o fondovima Europske unije. Stoga je pred njima nimalo jednostavan zadatak jačanja samoodrživosti i postizanja ravnoteže između kvalitetnog i poštenog korištenja sredstava fondova i izlaženja iz kruga ovisnosti o natječajima EU-a:

"Kada kod nas krenu EU fondovi postoji opasnost poplave društvenih poduzetnika i poduzeća, kao što je bio slučaj u Rumunjskoj jer je zapravo mali dio njih dugoročno održiv. Najgora je situacija da se samo dijeli novac." 55

"Sve su udruge uglavnom projektno financirane i ovisimo o fondovima u čemu leži ključ problema sektora jer da bi bio društveni poduzetnik moraš biti održiv i ne isključivo ovisan o tome da li je izašao natječaj i hoćeš li proći... Najgori je scenarij čekati dvije godine da izađe natječaj za tebe što je za društvene poduzetnike gubitak vremena i zastoj u poslovanju." ${ }^{6}$

\footnotetext{
52 Vera Gjokaj, konzultantica, Cedra - klaster za eko-društvene inovacije i razvoj; intervju.

53 Do 2020. spremno je 85 milijuna eura preko EU-ovih natječaja i fondova kroz Europski socijalni fond, Europski fond za regionalni razvoj, Europski poljoprivredni fond za ruralni razvoj itd.

54 Vera Gjokaj, intervju.

55 Dr. sc. Šimleša, Dražen, intervju.

56 Vera Gjokaj, intervju.
} 


\subsection{O REFORMI ZAKONODAVNOG OKVIRA DRUŠTVENOG PODUZETNIŠTVA U HRVATSKOJ}

Iako ozbiljniji zaključci zakonodavnog okvira traže ekstenzivniju analizu, u nastavku se daje preliminarni uvid u stanje u kojem djeluje domaći društveni poduzetnik. Situaciju jasno opisuje izjava ispitanika koji navodi kako RH još nema institucionalni okvir za ozbiljniji razvoj DP-a, predviđen europskom Strategijom 2020.. ${ }^{57}$

"Društveno poduzetništvo gotovo uopće nije regulirano zakonskim propisima osim kroz zakone o zadrugama i udrugama, dakle ne na jednom mjestu i ne sustavno. Obzirom da EU kroz Strategiju 2020 na razne potiče osnivanje i financiranje ovakvih oblika zapošljavanja, potrebno je što prije stvoriti pravni okvir za društveno poduzetništvo."58

Problematika zakonodavnog okvira je prilično kompleksna. U nastavku je pregled ključnih slabosti na koje uglavnom javno upućuju mnogi akteri domaće scene. Prije svega, poslovanje zadruga kao vodećih društvenih poduzetnika prema postojećim odredbama Zakona o zadrugama ${ }^{59}$ koje su nejasne i ograničavajuće za razvoj društvenog poduzetništva, a naglašena je problematika poreznog opterećivanja (točnije dvostrukog oporezivanja ostvarene dobiti) jer su zadruge kao društva osoba koja imaju zakonsku mogućnost obavljanja ekonomske djelatnosti $^{60}$ i obveznici poreza na dobit prema Zakonu o porezu na dobit. Očigledan je veliki jaz između postojećeg stanja zadrugarstva u Hrvatskoj i potencijal koje ono ima. Babić i Račić ocjenjuju

“(...) RH uvelike zaostaje i po udjelu članova zadrugara u ukupnom broju stanovnika i po udjelu zaposlenih sektora zadrugarstva u ukupnom aktivnom stanovništvu. Potonji pokazatelj se za Republiku Hrvatsku u 2009. godini kretao na razini od oko 0,2 \%, a primjerice u Italiji isti udio iznosi 5\%, u Francuskoj je veći od 3\%, a u najvećem broju članica Europske unije ovaj pokazatelj se kreće između 2 i 3\%. Primjerice, kada bi se taj pokazatelj u Hrvatskoj popeo na 2\%, sektor zadrugarstva trebao bi imati više od 30.000 zaposlenih, odnosno oko deset puta više nego danas." 61

Za Udruge je zapreka neefikasna i nedovoljno informirana administracija te zakonska ograničenja profitnih aktivnosti (što je relativno ublaženo mogućnošću osnivanja trgovačkih društava $^{62}$ ) dok gospodarske djelatnosti prije svega moraju biti određene Statutom ${ }^{63}$ udruge.

57 Strategija Europa 2020. desetogodišnja je strategija Europske unije za rast i zapošljavanje. Pokrenuta je 2010. kako bi se stvorili uvjeti za pametan, održiv i uključiv rast.

58 Ispitanik želi ostati anoniman, intervju obavljen elektroničkom korespondencijom.

59 Zakon o zadrugama Narodne novine, broj 34/2011.

60 Zakon o zadrugama 34/11 čl. 35; (1) Zadruga može obavljati djelatnost s ciljem stjecanja dobiti. (2) Zadruga može obavljati djelatnost u cilju udovoljavanja potreba svojih članova bez namjere stjecanja dobiti (socijalna, potrošačka, stambena zadruga, zadruga lokalne zajednice, itd.).

61 Babić, Z., Račić, D., Zadrugarstvo u Hrvatskoj: trendovi, pokazatelji i perspektiva u europskom kontekstu, Sociologija i prostor, vol. 49, br. 3 (191), 2011., str. 287.-311., https://doi.org/10.5673/sip.49.3.2.

62 "Zakon nije propisao, ali udruge također mogu, radi obavljanja gospodarskih djelatnosti u svrhu ostvarivanja ciljeva utvrđenih statutom, osnivati trgovačka društva, zadruge ili druge gospodarske subjekte, sukladno posebnim propisima, a uzajamne odnose urediti ugovorom", Središnji državni portal - Gospodarska djelatnost udruga, https://gov.hr/moja-uprava/aktivno-gradjanstvoi-slobodno-vrijeme/udruge/gospodarska-djelatnost-udruga/1567, pristupljeno 15. veljače 2019. 
Ispitanici kao ključne barijere prepoznaju administrativno zagušenje, zakonodavnu nejasnoću i porezno preopterećenje društvenih poduzetnika:

"Unatrag godine dvije postrožen je zakon o udrugama što nije loše, no ima puno administracije i papirologije. Imati udrugu danas je gotovo isto kao imati poduzeće... Zakon o zadrugama je loš, preopćenit i zapravo ništa ne regulira. Nakon osnivanja, zadruge posluju po Zakonu o trgovačkim društvima gdje dolazi i do diskriminacije zbog Zakona o porezu na dobit. No nemoguće je nešto potvrditi bez dubinske analize zakonodavstva." 64

Postojeći fiskalni sustav nema posebne kriterije za društvene poduzetnike:

“Najvažniji element u tome je obveza plaćanja poreza na dobit koji iznosi 20\%. Drugim riječima, iako je poduzeće osnovano s namjenom ostvarivanja prihoda i dobiti koja će se usmjeravati na projekte socijalne svrhe ili ako je osnovano radi zapošljavanja teže zapošljivih osoba, i dalje će se tretirati kao bilo koje trgovačko društvo i neće biti izuzeto plaćanja poreznih obveza. Izuzetak su odnedavno zadruge socijalnog tipa koje se mogu tretirati kao neprofitne organizacije."65

Potrebno je razmotriti mjere kojima bi se razradio sustav poreznih olakšica koji bi se izričito odnosio na društvene poduzetnike i aktere socijalne ekonomije. Postojanje posebnih modela društvenih poduzeća kao možebitni put olakšanja poslovanja društvenih poduzetnika ${ }^{66}$ još je jedno od važnih pitanja koje se razmatraju unutar zakonodavne sfere dok se oko donošenja posebnog zakona o društvenom poduzetništvu ispitanici slažu da ne mora biti garancija ubrzanja procesa koji se upravo događaju:

"Uz zadruge, ključne su udruge i trgovačka društva pri čemu prvenstveno mislim na d.o.o.-e, no bilo bi dobro uvesti model neprofitnog trgovačkog društva kako je to praksa u većini drugih EU zemalja." ${ }^{7}$

"Nisam sigurna da bi uopće trebalo importirati bilo koji model, mislim da to treba uobličiti društveni kontekst - kulturni i tradicijski, a taj bi proces trebalo iznjedriti društvo za sebe. Moguće je poslužiti se modelima, ali smatram da copy-paste varijante neće donijeti uspjeh." 68

"Realno govoreći većina zemalja koje gledamo s divljenjem imaju zaseban pravni subjekt društvenog poduzeća iako su ostavili i zadruge i udruge." ${ }^{\prime}$

"Ljuti me da se zadruge forsiraju kao jedini oblik društvenih poduzeća... Kod nas ima mjesta za sve oblike poslovanja; udruge, zadruge, d.o.o.-i j.d.o.o-i. ${ }^{70}$

64 Teo Petričević, direktor ACT Grupe, stručnjak na području društvenog poduzetništva i društvene ekonomije, intervju obavljen elektroničkom korespondencijom.

65 Vidović, D., op. cit. u bilj. 35, str. 184.

66 "Svakako se kao značajan pomak može prepoznati nedavno zakonsko priznavanje statusa 'socijalnog' posebnim tipovima zadruga”. Vidović, D., op. cit. u bilj. 35, str. 180.

Teo Petričević, intervju obavljen elektroničkom korespondencijom. 
"Po meni zakon treba biti rezultat potrebe. Slovenija je tu pogriješila jer je prvo stvorila zakon, a tek onda krenula s razvojem sektora. Shvatili su naknadno da ih je zakon ograničio." ${ }^{71}$

Veći problem trenutačno predstavlja činjenica neprovođenja nijedne mjere Strategije. Naime, ni nakon dvije godine od donošenja i dalje nije ustanovljena Evidencija društvenih poduzetnika ${ }^{72}$ niti je ustanovljeno tijelo ili imenovani stručnjaci koji bi obavili dubinsku zakonodavnu analizu i time dali podlogu za početak reformi najavljenih Strategijom.

"Strategija je sjajno detektirala četiri osnovna područja na kojima treba raditi, na svakom od njih ima još jako puno posla i u svakom je potrebna po jedna osoba kao koordinator jer se radi o ogromnim sustavima." ${ }^{73}$

"Dubinska analiza zakonodavnog okvira je planirana Strategijom DP, ali se iz strategije niti jedna mjera nije provela." 74

Vidovićc $^{75}$ uz ostale slabosti zakonodavnog sustava navodi i "nepostojanje preciznog određenja koncepta 'općeg dobra' te priznavanje posebnog statusa takvim organizacijama kako bi se moglo utjecati i na razvijanje posebnih poticajnih politika i mjera". Osim toga, nerijetko se postavlja pitanje preuzimanja gotovih pravnih rješenja odnosno najboljih praksi iz EU-a. U tom scenariju vrijedi imati u vidu da uz postojeće (prethodno analizirane) pravne oblike i prakse, može se očekivati rizik ishoda karakterističan za pravne transplantate ${ }^{76}$ koji se onda pretvaraju u 'pravne iritante'. ${ }^{77}$ Razlog je najčešće u neskladu formalnih i neformalnih pravila, odnosno otporu neformalnih, duboko ukorijenjenih, pravila ponašanja prema novim i promjenjivim pravilima i zakonima. ${ }^{78}$

\subsection{PITANJA JAVNE NABAVE}

Društveno poduzetništvo u okviru javne nabave, do sada se uglavnom provodilo preko djelatnosti radne integracije, tzv. zaštitnih radionica (tvrtki koje zapošljavaju više od 51\% osoba

71 Vera Gjokaj, intervju.

72 Tijelo koje bi predstavljalo pandan Registru udruga.

73 Dr. sc. Dražen Šimleša, intervju.

74 Teo Petričević, intervju.

75 Vidović, D., op. cit. u bilj. 35, str. 183.

76 Kurkchiyan, M., Russian Legal Culture: An Analysis of Adaptive Response to an Institutional Transplant. Law \& Social Inquiry, vol. 33, br. 2, 2009., str. 337.-364.

Legrand, P., The Impossibility of Legal Transplants. Maastricht Journal of European and Comparative Law. vol. 4, 1997., str. 111. -124 .

77 Teubner, G., Legal Irritants: How Unifying Law Ends Up in New Divergences. u: P. A. Hall \& D. Soskice (ur.). Varieties of Capitalism: The Institutional Foundations of Comparative Advantage, Oxford University Press, Oxford, 2001., str. 417.-441.

78 Šimić Banović, R., Is Culture an Underpinning or Undermining Factor in the Business Environment of the Transitional Countries?, u Ateljević, J. \& Trivić, J. (ur.). Economic Development and Entrepreneurship in Transition Economies: Issues, Obstacles and Perspectives, Springer International Publishing, 2016., str. 11.-37., DOI 10.1007/978-3-319-28856-7.

Šimić Banović, R., From promising institutional transplants to legal irritants: Some institutional aspects, ITEMA 2017 Budapest Conference Proceedings 'Recent Advances in Information Technology, Tourism, Economics, Management and Agriculture', Association of Economists and Managers of the Balkans, Belgrade, 2017., str. 290.-301. 
s invaliditetom), a koje su implementirane Zakonom o profesionalnoj rehabilitaciji i zapošljavanju osoba s invaliditetom (Narodne novine, broj 157/2013, 152/2014).

"Kako je početkom godine stupio na snagu novi Zakon o javnoj nabavi, tek treba vidjeti njegovu primjenu obzirom da pojedini pojmovi iz novog zakona nisu poznati u hrvatskom pravu, odnosno tek ih trebamo usvojiti. Primjerice, radnici u nepovoljnom položaju i rezervirani ugovori. iako EU direktive ih poznaju i definiraju, mi još ne barem koliko je meni poznato." 79

U okviru postojećeg sustava javne nabave ${ }^{80}$ nedavno su implementirane i odredbe Direktive 2014/24/EU Europskog parlamenta o javnoj nabavi na temelju koje je dana mogućnost naručiteljima da pravo sudjelovanja u postupcima javne nabave "rezervira" zaštićenim radionicama i gospodarskim subjektima čiji je osnovni cilj društvena i profesionalna integracija osoba s invaliditetom ili osoba u nepovoljnom položaju. Ispitanici zaključuju kako je donošenje novog zakona o javnoj nabavi povećalo mogućnosti za društvene poduzetnike zbog kriterija javne nabave: ekonomski najpovoljnije ponude, instrumenta rezerviranih ugovora, socijalnih klauzula, socijalnih, zelenih i drugih kriterija:

"Na terenu radimo male korake ali se krećemo; nedavno smo pokrenuli bazu podataka ${ }^{81}$ i radimo na priručniku za javnu nabavu..."

"Javna nabava poznaje instrumente kojima daje mogućnost pozitivne diskriminacije za zaštitne radionice, ali ga drugi zakoni ne slijede." ${ }^{3}$

"Do donošenja tog novog zakona, nije bilo previše mogućnosti za društvene poduzetnike. Kako je Hrvatska visoko korumpirano društvo, po meni će trebati godine da se odmaknemo od tzv. "rođo - veza" prema transparentom postupku održive javne nabave." ${ }^{84}$

\subsection{ULOGA I VAŽNOST ZADRUGARSTVA U RH}

Broj registriranih zadruga u Hrvatskoj (uključujući i socijalne zadruge) porastao je s 12.000 tijekom devedesetih na 50.000 tisuća u $2013 .{ }^{85}$ Osim što tradicionalno djeluju u sektorima obrazovanja, kulture, sporta, vođene humanitarnim te širokim socijalnim ciljevima, novi je trend prisutan i u aktivnostima društvenog poduzetništva u sektorima obnovljivih izvora energije

79 Izvor želi ostati anoniman, intervju obavljen elektroničkom korespondencijom.

80 Novi zakon o javnoj nabavi stupio je na snagu 1. siječnja 2017., Narodne novine, broj 120/2016, Zakon o javnoj nabavi.

81 Održivi proizvodi, www.odrzivi-proizvodi.hr.

82 Teo Petričević, intervju.

83 Izvor želi ostati anoniman, intervju obavljen elektroničkom korespondencijom.

84 Teo Petričević, intervju.

85 Novkovic, S., Golja, T., Cooperatives and Civil Society: Potential for Local Cooperative Development in Croatia, Journal of Entrepreneurial and Organizational Diversity, Vol. 4, No. 1, 2015. str. 153.-169., Dostupno na SSRN: https://ssrn.com/ abstract $=2639147$. 
čiji je uspješan primjer energetska zadruga na Krku EOK ${ }^{86}$ i Zelena energetska zadruga ZEZ, ${ }^{87}$ zatim etičkog financiranja preko osnivanja prve domaće etičke banke ${ }^{88}$ i agro poslovanja (uljari, vinari i proizvođači sireva). ${ }^{89}$

Zadruge u kontekstu društvenog poduzetništva najčešći su osnivači ili članovi takvih poduzeća ${ }^{90} \mathrm{i}$ to zasad preko radne integracije kroz socijalne zadruge, ${ }^{91}$ dok je u Hrvatskoj, institucionalna podrška razvoju zadružnog poduzetništva dana djelovanjem krovne organizacije Saveza zadruga, ${ }^{92}$ odnosno Centra za zadružno poduzetništvo - javne ustanove zadužene za praćenje i razvoj zadružnih poduzetničkih kapaciteta i provedbu nacionalnih strategija. Uz postojeće slabosti javne politike, ${ }^{93}$ razlike između funkcioniranja novih i starih formi zadruga te doživljavanje zadruga kao relikta komunizma koje je karakteristično uglavnom za većinu tranzicijskih zemalja jugoistočne Europe ipak se može zaključiti kako zadruge tek započinju svoj novi uzlet te imaju priliku kroz veliki potencijal i podršku svojih članova (i konkretniju javnu politiku) biti pokretač regionalnog i lokalnog razvoja. Naime, novo zadrugarstvo pod kišobranom je civilnog sektora i u zajedničkoj misiji otvoreno mnogobrojnim dionicima i novim industrijama, dok je kod starih zadruga korist usmjerena prema vlastitom članstvu. Razvoj zadruga osobito je bitan u sferama koje komplementiraju održivosti lokalne ekonomije i inovativnim pristupima stvaranja novih vrijednosti korištenjem obnovljivih izvora energije (sunca, vode i vjetra), održivog ${ }^{94}$ gospodarenja otpadom; ${ }^{95}$ dinamičke, eko- poljoprivrede, organskog uzgoja hrane te mogućnosti financiranja novih poduzetničkih pohvata i prema principima etičkog bankarstva.

\subsection{VIDLJIVOST DRUŠTVENOG PODUZETNIŠTVA I KOMPETENCIJE DRUŠTVENIH PODUZETNIKA}

Vrlo nisku razinu sustavnog praćenja stanja na nacionalnoj razini, moguće je izmijeniti pojačanjem istraživačkih aktivnosti i time izgraditi konkretniju bazu podataka s vidljivim ekonomskim učincima aktera. Nadalje, uspostavljanjem sustava markiranja proizvoda i usluga jasnije bi se tržišno odredili proizvodi-usluge vođeni kriterijima više dodane vrijednosti, kvali-

86 Energetska zadruga otok Krk, http://www.h-alter.org/vijesti/ako-moze-krk-moze-i-cijela-hrvatska (15. studenog 2018.).

87 Zelena energetska zadruga, http://www.zez.coop/, pristupljeno 15. studenog 2018.

Etična banka, https://www.ebanka.eu/. Projekt koordinira grupa društvenih poduzetnika i organizacija civilnog društva.

Novković, S., Golja, T., (op. cit. u bilj. 87) navode brojne iznimne rezultate maslinarske zadruge diljem Dalmacije i Istre.

Prisutnost socijalnih zadruga uglavnom je vidljiva u aktivnostima radne integracije marginaliziranih grupa. Veliki dio zadruga ratnih veterana pripada kategoriji kvazi-zadruga (Novković, S., Golja, T., (op. cit., note 90).

Zakon o zadrugama, čl. 66., st. 1.

Hrvatski savez zadruga, http://www.zadruga.obz.hr/index.php/hrvatski-savez-zadruga.

Zakon o održivom gospodarenju otpadom Narodne novine, broj 94/2013 definira: “(...) postupci gospodarenja otpadom su: sakupljanje otpada, interventno sakupljanje otpada, priprema za ponovnu uporabu, priprema prije uporabe i zbrinjavanja, postupci uporabe i zbrinjavanja, trgovanje otpadom, posredovanje u gospodarenju otpadom, prijevoz otpada, energetska oporaba određenog otpada, sakupljanje otpada u reciklažno dvorište i privremeno skladištenje vlastitog proizvodnog otpada". 
tetnom informativnom strategijom odnosa s javnošću ${ }^{96}$ doprinijelo bi se višoj građanskoj osviještenosti i davanju zaslužene podrške i ohrabrenja lokalnim inicijativama, aktivistima, volonterima i općenito društvenim poduzetnicima. Umrežavanjem preko radionica, konferencija, ${ }^{97}$ edukacija i promotivnih aktivnosti pod visokim pokroviteljstvom Vlade, pojedinih ministarstva ili upravnih tijela lokalne i regionalne vlasti pridonijelo bi se informiranosti, protočnosti ideja i javnoj podršci s najviših razina javne vlasti. Institucionalna okolina na nacionalnoj i regionalnoj razini poput Ministarstva rada i mirovinskog sustava koje inače prati ostvarivanje ciljeva Strategije razvoja društvenog poduzetništva uz ostala tijela; ${ }^{98}$ osim javne podrške društvenim poduzetnicima trebala bi aktivirati instrumente javne politike, kvalitetnije usmjeriti proračunska sredstva u javno-privatne programe.

Iako se često navodi da u Hrvatskoj obrazovanje i programi visokog obrazovanja i dalje nisu u znatnijoj prepoznali temu društvenog poduzetništva, potrebno je ipak naglasiti i primjere dobre prakse. Veleučilište VERN već niz godina izvodi izborni kolegij Socijalnog poduzetništva i društvenih inovacija, Ekonomski fakultet Sveučilišta u Zagrebu i Ekonomski fakultet Sveučilišta u Osijeku osim kolegija Poduzetništva pridonosi i praktičnim djelovanjem Ekonomske klinike, Sveučilište Juraj Dobrila u Puli relevantnim znanstvenim radovima bavi se temama solidarne ekonomije, Pravni fakultet Sveučilišta u Zagrebu na Studiju socijalnog rada uveo je kolegij Socijalna ekonomija i socijalno poduzetništvo. ACT grupa je u listopadu 2018. pokrenula Akademiju poslovnih vještina ${ }^{99}$ za vodeće kadrove organizacija civilnog društva i društvenih poduzeća kojima kroz inovativnu suradnju ključna znanja i vještine prenose stručnjaci iz korporativnog sektora. Sve veću potrebu tržišta za konkretnijim edukacijskim mjerama vrlo je jasno uobličila Ćorić ${ }^{100}$ razmatrajući ključne edukacijske mjere koje bi domaći sustav obrazovanja trebao poticati kako bi se sektor društvenog poduzetništva nastavio razvijati:

- na studijima poduzetništva uvesti kolegij Društvenog poduzetništva te nastaviti upoznavati studente s temom u okviru odgovarajućih kolegija

- razvijati značajniju suradnju s organizacijama civilnog društva koje promiču i/ili provede društveno poduzetništvo

- omogućiti studentima obavljanje studentskih praksi, volontiranja i/ili društveno korisnog učenja u tim organizacijama

- pozivati društvene poduzetnike kao goste na predavanjima iz poduzetništva ili poslovne etike uz mogućnost zadavanja praktičnih zadataka ili uključivanja studenata u konkretne projekte s društvenim poduzetnicima.

Unutar segmenta obrazovanja vrlo aktualnim postaje pitanje jačanja poduzetničkih vještina i kapaciteta ljudi koji uglavnom dolaze iz civilnog sektora i ne poznaju dovoljno zakonitosti tržišnog pristupa i profitnog poslovanja. Na te potrebe svatko treba obratiti pozornost. Osno-

96 Primjer kvalitetnog novinarstva održivog razvoja pruža The Guardian Sustainable, https://www.theguardian. com/uk/ sustainable-business.

97 Primjer dobre prakse umrežavanja je Konferencija o dobroj ekonomiji.

98 Ministarstvo za demografiju, obitelj, mlade i socijalnu politiku; Ministarstvo gospodarstva, maloga i srednjega poduzetništva i obrta; Ministarstvo regionalnog razvoja i fondova Europske unije i Ured Vlade Republike Hrvatske.

100 Mr. sc. Gordana Ćorić, konzultantica i predavačica kolegija Socijalnog poduzetništva i društvenih inovacija na Veleučilištu VERN, intervju obavljen elektroničkom korespondencijom. 
ve poduzetničkih kompetencija kao i marketinških i prodajnih znanja osnovna su preporuka ispitanika uz jedan zanimljiv stav karakterističan za Ashtoka pristup change makera društva.

"Osnovni način razmišljanja koji nedostaje civilnom sektoru velikim dijelom jesu i ljudi s poduzetničkim duhom. A to znači ne samo znati razmišljati projektno već i prodajno, biti spreman s vizitkom u torbi ili proizvodom u torbi!"101

"Mislim da dobri socijalni ili društveni poduzetnici imaju određenu dozu karizme da povedu druge prema nekoj svojoj viziji. Uz to su povezani s lokalnom zajednicom i utjelovljuju lijepe ljudske vrijednosti: poštenja, upornosti, savladavanja prepreka, socijalne osjetljivosti jer su doslovno osjetili neki problem pa je socijalna misija njihov drive." 102

“Vrlo je važno i potrebno razvijati odgovarajuće poslovne vještine kao što su prezentacijske vještine, vještine planiranja, izrada okvirnih poslovnih planova, izrada marketinških planova, razradu strategija i scenarija rasta, razmatranje alternativnih načina financiranja poduzetničkih pothvata." ${ }^{103}$

Još jedan važan segment obrazovanja jest poticanje inovativnosti u obrazovanju kroz različite programe visokog obrazovanja ali i praktičnu snagu igre, istraživačke aktivnosti i kreativnosti kojom se snaži duh djece još od vrtićke dobi. Istraživanje u studentskoj populaciji ${ }^{104}$ pokazalo je da je empatija prema čovječanstvu presudni pokretački faktor za buduće socijalne poduzetnike. Paulijev ${ }^{105}$ stav je da poslovni sektor treba naći mogućnosti za adresiranje potreba društva uz poštovanje pravila prirode, a to u konačnici iziskuje inovativne poslovne modele. On je na posljednjoj Konferenciji za dobru ekonomiju 2016. predložio konkretnu inventuru poslovnih prilika koje se u okvirima "plave ekonomije"106 i održivog razvoja mogu provesti u Hrvatskoj. ${ }^{107}$ Te se prilike zasigurno nalaze u sektorima proizvodnje i usluga više vrijednosti poput održivog upravljanja otpadom, energetskog sektora, eko-agroturizma, kulturnog turizma i edukacija.

\section{ZAKLJUČAK}

Društveno poduzetništvo relativno je nov ekonomski, pravni i sociološki fenomen i kao takav u svjetskim i domaćim razmjerima trenutačno prolazi svojevrsnu inicijaciju opstanka i razvoja. Buđenju ekonomije solidarnosti i vrijednosti socijalnih inovacija svjedoči impresiv-

\footnotetext{
101 Andreja Rosanić, intervju.

102 Dr. sc. Davorka Vidović, Odsjek za hrvatsku politiku, Fakultet političkih znanosti, intervju.

103 Mr. sc. Gordana Ćorić, intervju.

104 Kedmenec, Irena, et al. The Impact of Individual Characteristics on the intentions to pursue Social Entrepeneurship. Ekonomski pregled, vol. 66, br. 2, 2015., str. 119.-137., https://hrcak.srce.hr/139350.

105 Pauli, G., Plava ekonomija: 10 godina, 100 inovacija, 100 milijuna radnih mjesta. Katarina Zrinski, Zagreb, 2012.

106 Bušljeta Tonković, A., Gunter Pauli, Plava ekonomija: 10 godina, 100 inovacija, 100 milijuna radnih mjesta. Izvješće podneseno Rimskom klubu. Sociologija i prostor, 51 (2013) 195 (1), str. 150.-154

107 "Provjerena je činjenica kako za proizvodnju ekoloških proizvoda u Hrvatskoj koristimo samo 0,6 posto poljoprivrednih površina” - Vera Gjokaj, intervju.
} 
na brojka od čak dva milijuna društveno-ekonomskih entiteta koji znatno doprinose cjelokupnom europskom poslovanju šarolikosti pravnog okvira (zadruge, uzajamna društava, udruge i fondacije, neprofitna društva). Vrlo je jaka europska institucionalna podrška društvenom poduzetništvu i oblicima solidarne ekonomije preko različitih institucija (Europska komisija, Parlament, Europski ekonomski i socijalni odbor). Vidljivost društvenog poduzetništva u EU-u varira od zemlje do zemlje, no njezino postojanje neizbježno izbija u različitosti oblika i djelovanja pa se može zaključiti da je danas u Europi trend triju osnovnih mogućnosti djelovanja društvenih poduzeća. Prvo, zemlje koje uspješno afirmiraju zadružne oblike društvenih poduzeća (najpoznatiji primjer je Mondragon u Španjolskoj te regija Baskija, Italija, Danska i pojedine zemlje jugoistočne Europe). Drugu grupu zemalja primarno čine Belgija, Velika Britanija i Švedska. One imaju nešto otvoreniji pristup (hibridnih) modela bliži privatnim poduzećima i sa širom društvenom svrhom (neprofitnih privatnih poduzeća). U drugu grupu pripadaju i Njemačka i pojedine skandinavske regije u kojima je naglašena sloboda u izboru navedenih modela. Trećoj grupi zemalja pripadaju Poljska, Slovačka i Finska. U tim se zemljama primarno razvija model društvenih poduzeća preko radne integracije. Taj WISE pristup vrlo je vrijedan i razvijen, no pomalo i ograničavajući oblik društvenog poduzetništva jer mu je primarna uloga integracija socijalno-radnom terapijom, a manje poduzetničko pozicioniranje na tržištu. Stoga je preporuka mnogih znanstvenika i aktera ne poistovjećivati ga s isključivim oblikom društvenih poduzeća. Današnja društvena poduzeća u zapadnoeuropskim zemljama najčešće su okrenuta društvenim inovacijama zbog naglašene potrebe za novim proizvodima i uslugama. Istodobno, zemlje sa slabijom socijalnom kohezijom amortiziraju praznine u djelatnostima uglavnom socijalne skrbi jer ih tijela javne politike svojim mjerama više nisu u stanju adekvatno zadovoljiti.

$S$ druge strane trenutačno se događa renesansa u području razvoja terminologije i pravnog usustavljivanja društvenog poduzetništva. Pojedini autori iz područja socijalnog privatnog prava stoga naglašavaju dužnost i obvezu aktera društvenog poduzetništva da zbog pravne sigurnosti i vidljivosti na tržištu uz višu dodanu vrijednost svojih proizvoda i usluga - svakako koriste naziv društveni poduzetnik. Talijani kao predvodnici socijalnog zadrugarstva u svom su pristupu društvenom poduzetništvu obogatili područje raznovrsnošću oblika i zakonskog definiranja pojedinih modela (Impresa Sociale). Ipak, i kod njih se naglašava potreba trećeg sektora za još dubljom reformom prije svega fiskalnog rasterećenja društvenih poduzeća dok (socijalne) zadruge i dalje ostaju vodeći izbor društvenih poduzetnika, uvjetovan tradicijskim i praktičnim razlozima. Velika Britanija očiti je outlier. Razlozi se ponajprije nalaze u prihvaćenosti društvene ekonomije i poduzetništva te orijentiranosti na kreiranje poticajne javne politike spram aktera društvenog poduzetništva. Nastavljaju se otvorenošću javne nabave prema akterima društvene ekonomije (Social Value Act), uvođenjem posebnih poduzeća poput Community Interest Company, razvijenim tržištem investicijskog socijalnog kapitala (socijalne banke, različite investicijske organizacije i fondove venture filantropije) i konačno inovativnim modelima javno-privatnog partnerstva (Social Bond Investment). Slijedom prezentiranog, može se zaključiti da se u Europi događa regulatorni inovacijski procvat društvenog poduzetništva vođen potrebom nadogradnje postojećih pravnih entiteta trećeg sektora uz razvoj novih i "egzotičnih" pravnih područja poput privatnog prava društvenih poduzeća. Ovo vrlo intenzivno razdoblje zasigurno će rezultirati promjenom ustaljenih normativnih paradigmi i zakonodavnih mitova društvenog i poduzetničkog djelovanja. 
Ovaj rad pokušao je (re)afimirati relevantnost društvenog poduzetništva u Hrvatskoj. SWOT analiza temeljena na analizi postojećih dokumenata i intervjuima s ključnim akterima ukazuje na nekoliko činjenica. Kao najvažnije karakteristike društvenog poduzetništva prepoznate su održivost, participativnog upravljanja poslovnim procesima, reinvestiranje dobiti $\mathrm{u}$ šire društvene potrebe zajednice, socijalne inovacije i preispitivanje odnosa prema ljudima, okolišu i vrijednosti novca. Najznačajnija otvorena pitanja jesu reforma zakonodavnog okvira, razrada sustava fiskalnih mjera, vidljivost društvenih poduzeća na tržištu, sudjelovanje u postupcima javne nabave, uloga zadrugarstva, uspostava sustava markiranja proizvoda, kvaliteta informativne strategije odnosa s javnošću, umrežavanje društvenih poduzetnika te aktivniji odnosom javne politike prema ovoj temi u cjelini. Ispitanici najviše kritiziraju provedbu zakonodavne reforme, posebice fiskalnog rasterećenja. Također ističu potrebu za jasnom zakonskom distinkcijom ove djelatnosti kako bi se društvenim poduzetnicima u Hrvatskoj dala pravna sigurnost, uveo red među stvarnim akterima i omogućila tržišna vidljivost.

Hrvatska nema poseban zakon kojim regulira područje društvenog poduzetništva pa je zasad njegov zakonski okvir određen postojećim pozitivnim zakonodavstvom ${ }^{108}$ i Strategijom za razvoj društvenog poduzetništva 2015. - 2020. Osim toga, i u Strategiji borbe protiv siromaštva i socijalne isključenosti 2014. - 2010 društveno poduzetnička aktivnost spominje se kao moguća mjera povećanja zaposlenosti i smanjenja regionalnih razlika. No, u tom kontekstu možemo pogrešno doživjeti koncept društvenog poduzetništva kao panaceju za rješavanje dugotrajnih bolesti društva. Činjenica da društveno poduzetništvo ulazi u Hrvatsku u posljednjim desetljećima uglavnom kroz vrata civilnog sektora implicira udruge kao dominantan pravni okvir djelovanja domaćih društvenih poduzetnika. Zadruge su zasad podcijenjene iako širom Europe pokazuju izvrsne rezultate. Čini se da zadruge kod nas i dalje akumuliraju otpor i nepovjerenje uvjetovano percepcijom prošlosti. Navedene modele i njihove postojeće pozitivno pravne norme vrijedilo bi podvrgnuti daljnjoj pravnoj analizi čime bi se fokusirao odgovor na pitanje: Kako bi ove forme društava osoba mogle doprinositi društvenim poduzetnicima u što jednostavnijem i efikasnijem provođenju njihovih društvenih ciljeva i zadataka? Kopiranje pravnih oblika karakterističnih za zemlje EU-a najvjerojatnije bi rezultiralo rizicima specifičnim za pravne transplantate i time predstavljao nepotreban formalno pravni eksperiment. Sustavnim revidiranjem neodrživih odredbi i unošenjem inovacija u oblike koji pozitivno pravni sustav RH već posjeduje (primarno udruge i zadruge) mogu se stvoriti uvjeti za optimalan pravni okvir djelovanja društvenog poduzetništva. Sinergijski učinak može se očekivati ako se intenzivira provedba Strategije za razvoj društvenog poduzetništva.

U Hrvatskoj već postoje prepoznate i održive društveno-poduzetničke inicijative koje su dijelom prikazane i u ovom radu. Dodatnim prepoznavanjem i vrednovanjem prednosti u području društvene ekonomije mogu se ojačati domaće društvene i ekonomske snage. Pritom je vrlo važna uloga obrazovanja, posebice visokoškolskih obrazovnih institucija i njihova otvaranja suvremenim kolegijima socijalnih inovacija i poduzetništva. Podizanjem kompetencija ljudi iz sektora i usmjeravanjem u područja iskonskih interesa umjesto slijeđenja trendova te

108 Zakon o zadrugama (Narodne novine, broj 34/2011, 125/2013, 76/2014); Zakon u udrugama (Narodne novine, broj 74/2014); Zakon o zakladama i fondacijama (Narodne novine, broj 106/2018); Zakon o ustanovama (Narodne novine, broj 76/1993, 29/1997, 47/1999, 35/2008); Zakon o trgovačkim društvima (Narodne novine, broj 152/2011, 111/2012); Zakon o profesionalnoj rehabilitaciji i zapošljavanju osoba s invaliditetom (Narodne novine, broj 143/2002, 33/2005, 157/2013); Zakon o javnoj nabavi (Narodne novine, broj 120/2016) i Zakon o poticanju razvoja malog gospodarstva (Narodne novine, broj 29/2002, 63/2007, 53/2012, 56/2013). 
poticanjem inovacija, kreativnosti i praktičnog rada može se stvarati i regenerirati kritična masa predanih pojedinaca, inicijativa i projekata koje doprinose progresivnijem društvenom i ekonomskom habitusu Hrvatske.

\section{LITERATURA}

\section{KNJIGE I ČLANCI}

1. Babić, Z., Račić, D., Zadrugarstvo u Hrvatskoj: trendovi, pokazatelji i perspektiva u europskom kontekstu, Sociologija i prostor, vol. 49, br. 3 (191), 2011., str. 287.-311., https://doi.org/10.5673/sip.49.3.2.

2. Banks, J. A., The Lives and Values of Researchers: Implications for Educating Citizens in a Multicultural Society. Educational Researcher, vol. 27, br. 7, 1998., str. 4.-17.

3. Baturina, D., A Critical Review of the First Strategy for the Development of Social Entrepreneurship in the Republic of Croatia 2015-2020 and potential for the development of the sector, Hrvatska i komparativna javna uprava, Poseban prilog uz br. 2/2018, 2018., str. 11.-38.

4. Bušljeta Tonković, A., Gunter Pauli: Plava ekonomija: 10 godina, 100 inovacija, 100 milijuna radnih mjesta. Izvješće podneseno Rimskom klubu. Sociologija i prostor, 51 (2013) 195 (1) str. 150.-154.

5. Chavez, C., Conceptualizing from the inside: Advantages, complications, and demands on insider positionality. The Qualitative Report, vol. 13, no. 3, 2008., str. 474.-494.

6. Defourny, J., From Third Sector to Social Enterprise: A European Research Trajectory, Routledge, New York, 2014., str. 17.-41.

7. Fici, A., Recognition and Legal Forms of Social Enterprise in Europe: A Critical Analysis from Comparative Law Perspective. Euricse Working Papers, 82|15, 2015.

8. Jurić, D., Europska zadruga, Pravo i porezi, 6/2006., str. 58.-67.

9. Kedmenec, I., et al. The Impact of Individual Characteristics on the intentions to pursue Social Entrepeneurship. Ekonomski pregled, vol. 66, br. 2, 2015., str. 119.-137., https://hrcak.srce.hr/139350, pristupljeno 7. prosinca 2017.

10. Kurkchiyan, M., Russian Legal Culture: An Analysis of Adaptive Response to an Institutional Transplant. Law \& Social Inquiry, vol. 33, br. 2, 2009., str. 337.-364.

11. Legrand, P., The Impossibility of Legal Transplants. Maastricht Journal of European and Comparative Law. vol. 4, 1997., str. 111.-124.

12. Lupšić, D., Bajok, I., Medić, M., Glavina Petričević, S., Petričević, T., Fruchterman, J., Poduzetništvo u službi zajednice - Zbornik radova o društvenom poduzetništvu, Nacionalna zaklada za razvoj civilnog društva, Zagreb, 2012.

13. Levenson Keohane G., Social entrepreneurs for 21st century: Innovation Across the Nonprofit, Private, and Public Sectors. McGraw-Hill Education, 2013.

14. Marković, L., Baturina, D., Babić, Z., Socijalna poduzeća za radnu integraciju (WISE) u postsocijalističkim zemljama, Hrvatska revija za rehabilitacijska istraživanja, vol. 53, br. 1, 2017., str. 139.-158.

15. Pauli, G., Plava ekonomija: 10 godina, 100 inovacija, 100 milijuna radnih mjesta. Katarina Zrinski, Zagreb, 2012.

16. Patton, M. Q., Qualitative Research and Evaluation Methods. Thousand Oaks, CA: Sage, 2002.

17. Pestoff, V., The Role of Participatory Governance in the EMES Approach to Social Enterprise, Journal of 
Entrepreneurial and Organizational Diversity, vol. 2, no. 2, 2013, str. 48.-60.

18. Stubbs, P., Vidović, D., Social Enterprise in Transition: A Case Study of ACT Group, Društvena istraživanja, vol. 26, br. 2, 2017, str. 143.-163., https://doi.org/10.5559/di. 26.2.01.

19. Vincetić, Vlatka et al., Definiranje područja i potencijal razvoja socijalnog poduzetništva Hrvatske u komparativnom kontekstu, Ekonomski pregled, vol. 64, br. 3, 2013, str. 256.-278., https://hrcak.srce. $\mathrm{hr} / 105517$.

20. Šimić Banović, R., From promising institutional transplants to legal irritants: Some institutional aspects, ITEMA 2017 Budapest Conference Proceedings 'Recent Advances in Information Technology, Tourism, Economics, Management and Agriculture', Association of Economists and Managers of the Balkans, Belgrade, 2017., str. 290.-301.

21. Šimić Banović, R., Is Culture an Underpinning or Undermining Factor in the Business Environment of the Transitional Countries?, u Ateljević, J. \& Trivić, J. (ur.). Economic Development and Entrepreneurship in Transition Economies: Issues, Obstacles and Perspectives, Springer International Publishing, 2016, str. 11.-37., DOI 10.1007/978-3-319-28856-7.

22. Šimleša, D., Puđak, J., Majetić, F., Bušljeta Tonković, A., Mapiranje novih obzora: Izvještaj o stanju društvenog poduzetništva u Hrvatskoj, Institut Ivo Pilar, Zagreb, 2015.

23. Šimleša, D., Zeleni alati: dobra ekonomija, Zelena mreža aktivističkih grupa, Vukomerić, 2015.

24. Vidović, D., Socijalno poduzetništvo u Hrvatskoj. Doktorska disertacija. Filozofski fakultet, Sveučilište u Zagrebu, 2012.

25. Teubner, G., Legal Irritants: How Unifying Law Ends Up in New Divergences. u P. A. Hall \& D. Soskice (ur.). Varieties of Capitalism: The Institutional Foundations of Comparative Advantage, Oxford University Press, Oxford, 2001., str. 417.-441.

\section{POPIS PROPISA, AKATA I SUDSKIH ODLUKA}

1. Direktiva 2014/24/EU Europskog parlamenta i Vijeća od 26. veljače 2014. o javnoj nabavi i o stavljanju izvan snage Direktive 2004/18/EZ.

2. Strategija razvoja društvenog poduzetništva za razdoblje od 2015. do 2020. Zagreb, travanj 2015.

3. Uredba (EU) br. 1296/2013 Europskog parlamenta i Vijeća od 11. prosinca 2013. o programu Europske unije za zapošljavanje i socijalne inovacije.

4. Zakon o javnoj nabavi (Narodne novine, broj 120/2016).

5. Zakon o poticanju razvoja malog gospodarstva (Narodne novine, broj 29/2002, 63/2007, 53/2012, 56/2013).

6. Zakon o profesionalnoj rehabilitaciji i zapošljavanju osoba s invaliditetom (Narodne novine, broj 143/2002, 33/2005, 157/2013).

7. Zakon o trgovačkim društvima (Narodne novine, broj 152/2011, 111/2012).

8. Zakon o ustanovama (Narodne novine, broj 76/1993, 29/1997, 47/1999, 35/2008).

9. Zakon o zadrugama (Narodne novine, broj 34/2011, 125/2013, 76/2014).

10. Zakon o zakladama i fondacijama (Narodne novine, broj 106/2018).

11. Zakon u udrugama (Narodne novine, broj 74/2014). 


\section{MREŽNI IZVORI}

1. Cooperatives Europe: The Power of cooperation - Cooperatives Europe key figures 2015. Brussels, 2016. https://coopseurope.coop/sites/default/files/The\%20power \%20of\%20Cooperation\%20 -\%20Cooperatives\%20Europe\%20key\%20statistics\%202 015.pdf, pristupljeno 5. siječnja 2017.

2. European Commission - Social Business Initiative: Creating a favourable climate for social enterprises, key stakeholders in the social economy and innovation, Brussels, 2011. https://www.fi-compass. $\mathrm{eu} /$ sites/default/files/publications/social-business-initiative-creating-a-favourable-climate-for-social-enterprises-key-stakeholders-in-the-social-economy-and-innovation.pdf, pristupljeno 5. siječnja 2017.

3. European Commission, Silver Economy Study: How to stimulate the economy by hundreds of millions of Euros peryear. $2018 \mathrm{https} / /$ ec.europa.eu/digital-single-market/en/news/silver-economy-study-how-stimulate-economy-hundreds-millions-euros-year, pristupljeno 12. studenog 2018.

4. European Commission - Social Business Initiative http://ec.europa.eu/growth/sectors/ social-economy/enterprises-en, pristupljeno 10. prosinca 2016.

5. European Parliament resolution of 19. February 2009 on Social Economy (2008/2250(INI)) http:// www.europarl.europa.eu/sides/getDoc.do?pubRef=-//EP//TEXT+TA+P6-TA-2009-0062+0+DO$\mathrm{C}+\mathrm{XML}+\mathrm{V0} / / \mathrm{EN}$, pristupljeno 10. prosinca 2016.

6. Europska komisija, Društvena poduzeća i njihov eko-sistem u Europi, Brisel, 2015 URL=https://ec.europa.eu/social/main.jsp?catId=952\&intPageId=2914\&langId=en\#navtem-related, https://ec.europa.eu/social/BlobServlt?docId=12987\&langId=en, pristupljeno 17. veljače 2019.

7. EFESEIIS, New Generation Social Enterprises. Impact Hub GmbH, 2016. http://www.fp7-efeseiis.eu/ new-generation-of-social-enterprises/.

8. European Economic and Social Committee, Unlocking the Potential of the Social Economy for EU Growth: The Rome Strategy, 2014, http://socialeconom yrome.it/files/Rome\%20strategy-EN.pdf, pristupljeno 12. prosinca. 2016.

9. EMES http://www.emes.net, pristupljeno 15. prosinca 2016.

10. Energetska zadruga otok Krk: http://www.h-alter.org/vijesti/ako-moze-krk-moze-i-cijela-hrvatska, pristupljeno 15. studenog 2018.

11. Etična banka https://www.ebanka.eu/, pristupljeno 15. prosinca 2016.

12. Hrvatski savez zadruga http://www.zadruga.obz.hr/index.php/hrvatski-savez-zadruga, pristupljeno 10. prosinca 2017.

13. Milanska deklaracija http: www.eesc.europa.eu/?i=portal.en.events-and-ACTivities-boosting-innovation-milan-declaration, pristupljeno 10. prosinca 2017.

14. Mondragon http://www.mondragon-corporation.com/, pristupljeno 12. studenog 2016.

15. Nacionalna strategija stvaranje poticajnog okruženja za razvoj civilnog društva 2006-2011, Zagreb, 2007., https://udruge.gov.hr/UserDocsImages/dokumenti/Nacionalna \% 20strategija\%20stvaranja\%20poticajnog\%20okru\%C5\%BEenja\%20za\%20razvoj\%20 civilnog \%20dru\%C5\%A1tva\%20 2012-2016.pdf.

16. NESsT http://www.nesst.org/, pristupljeno 10. prosinca 2016.

17. Petričević, T., Zakonodavni i institucionalni okvir za razvoj društvenog poduzetništva u jugoistočnoj Europi, CEDRA, Čakovec, 2012., http://cedra.hr/assets/attach/posts/642/ socentlegalsee-hr.pdf, pristupljeno 10. prosinca 2017.

18. Strasburška deklaracija, http://ec.europa.eu/internal-market/conferences/2014/0116-social-entrepreneurs/declaration/index-en.htm, pristupljeno 15. prosinca. 2017. 
19. Središnji državni portal - Gospodarska djelatnost udrugahttps://gov.hr/moja-uprava/aktivno-gradjanstvo-i-slobodno-vrijeme/udruge/gospodarska-djelatnost-udruga/1567, pristupljeno 15. veljače 2019 .

20. The Guardian Sustainable; https://www.theguardian.com/uk/sustainable-business.

21. Zelena energetska zadruga http://www.zez.coop/, pristupljeno 15. studenog 2018.

22. WILCO http:// www.wilcoproject.eu, pristupljeno 10. studenog 2018.

\section{ISPITANICI}

1. Andreja Rosandić, ispitanica je u vrijeme intervjuiranja radila kao menadžer za održivost u NESsT Hrvatska, danas radi kao konzultantica u području društvenog poduzetništva.

2. doc. dr. sc. Davorka Vidović, Odsjek za hrvatsku politiku, Fakultet političkih znanosti.

3. dr. sc. Dražen Šimleša, društveni aktivist, sociolog i znanstvenik na Institutu Ivo Pilar; voditelj Centra za istraživanje integralne održivosti i održivog razvoja.

4. mr. sc. Gordana Ćorić, konzultantica i predavačica kolegija Socijalnog poduzetništva i društvenih inovacija na Veleučilištu VERN.

5. Teo Petričević, direktor ACT Grupe, stručnjak na području društvenog poduzetništva i društvene ekonomije.

6. Vera Gjokaj, ispitanica je u vrijeme intervjuiranja radila u Cedri- klaster za eko - društvene inovacije i razvoj, danas obavlja funkciju Voditeljice programa razvojnih potencijala, ZMAG.

7. Zaposlenik socijalnog poduzeća, anonimiziran na vlastiti zahtjev. 


\section{THE ANALYSIS OF THE SOCIAL ENTREPRENEURSHIP IN CROATIA WITH A COMPARATIVE REVIEW OF THE REGULATORY FRAMEWORK}

\section{Summary}

The article presents the results of the comparative analysis of the regulatory frameworks of social entrepreneurship in selected EU countries. It seeks to provide insights into the issue that would be of value for Croatia. Additional contribution of the research is the SWOT analysis of social entrepreneurship in Croatia based on the information obtained in the semistructured interviews with key entrepreneurs and experts in the field. The purpose of the article is twofold: firstly, to reaffirm social entrepreneurship and its potential, and secondly, to enhance the understanding and contribute to the discussion on the attempts to improve social entrepreneurship in Croatia.

Keywords: $\quad$ social entrepreneurship, social economy, regulatory framework 